\title{
Coping with Enlightenments
}

\author{
$1 \quad$ Viennese Struggles
}

Hell's own engagement with the problem of the general suppression of his order began as a recurrent theme in letters written during his Arctic expedition to the general of the Jesuit order in Rome, to Bishop Gondola in northern Germany, and to Jesuit friends in Vienna. Hell assured his correspondents that he was doing what he could to make a good impression of the Society of Jesus in Denmark-Norway. When rumors had it that the young king Christian might visit Rome in addition to London and Paris during his grand tour of 1768-69, Hell was full of hope that this would bring good news concerning future policies toward Catholics (and Jesuits) in the lands ruled by the Copenhagen court. ${ }^{1}$ As late as the spring of 1773 , in a letter to Weiss Hell assured his confrère that

things are going quite well with our Society, we are expecting more joyful news from Rome any day soon. One thing is certain: a declaration that is most favorable toward the Society has long since been sent from our court to Rome, not directly to the pope, as a false rumor has it, but to the kind of men from whom the pope is likely to be told about it, and by now he has been told. They say they have learned from a French letter something I think is highly likely to be true, namely that an instruction has been sent from the king of the French to his ambassador in Rome [François-Joachim de Pierre] Cardinal de Bernis [1715-94] that he shall from now on refrain from all negative actions against the Society vis-à-vis the pope; [...] after a week or two, we will learn from official news exactly what impression the declaration of our court has made in Rome. ${ }^{2}$

Fifteen weeks later, on July 21, Pope Clement XIV issued the Dominus ac redemptor noster, the draft of which had in fact been ready since the previous

1 See the letters edited by Pinzger, Hell Miksa, 2:48, 76, 80-81.

2 Hell to Weiss in Trnava, dated Vienna, April 6, 1773. Pinzger, Hell Miksa, 2:116-17. Neither the supposed "declaration" of the Viennese court, nor the "instruction" by the king of France, could be identified. As Hell's claims run counter to the current state of scholarship on the suppression of the Society of Jesus, they are puzzling. 
December, bringing an end to the Society of Jesus in all Catholic countries. On September 10, 1773, the suppression of the order in the entire Habsburg monarchy was officially announced and all its estates taken over by the state. ${ }^{3}$

If Hell was unable to read the signs of the times before the summer of 1773 , he seems to have made the first steps of adjustment quickly: half a year later, we already find him drafting plans for an Austrian academy of sciences, to be established in Vienna. ${ }^{4}$ This was already the fourth time such plans were entertained. The project drafted by Leibniz in the beginning and von Petrasch in the middle of the century were mentioned in Chapter 2. Apparently, in 1764 Hell himself wanted to revive the idea of an academy of sciences, again without success. ${ }^{5}$ According to the report of a Danish visitor of Hell's, this attempt failed because Hell rejected an (unnamed) minister's insistence that members of the academy should be appointed by the government. ${ }^{6}$ The government decision to review the possibility of establishing an academy of sciences in Vienna in January 1774 may have been actually triggered by the suppression of the Society of Jesus: scientific life in Austria would have to be reorganized anyway. Hell's invitation to participate in the project can be understood as a token of the measured disposition toward ex-Jesuits as individuals, urged by Kaunitz and pursued with some consistency as mentioned above. After all, the court astronomer was a significant asset: as of 1773 , he was at the height of his fame in the Republic of Letters, elected a member of prestigious scientific bodies in Copenhagen, Trondheim, Stockholm, Göttingen, and Bologna, as well as a corresponding member of the main scientific academy in the Catholic world, the Académie Royale des Sciences in Paris. Besides, Hell was not only an astronomer of international reputation but also an encyclopedist in the sense that his research interests encompassed historical research, language studies, geophysics, meteorology, magnetism, electricity, and so forth. As such, by strictly academic standards he hardly had any local competitor in the same league for the task.

Hell's "rival" in forging plans for an academy in the spring of 1774 was a recently appointed young professor of universal and literary history at the University of Vienna, Ignaz Mathes von Hess (1746-76), who opted for an institution consisting of two branches, a "physical-mathematical" and a

3 For a detailed chronological account, see Gerhard Winner, Die Klosteraufhebungen in Niederösterreich und Wien (Vienna: Herold, 1967), esp. 33-48.

4 The literature includes Feil, Versuche, 45-69; Haberzettl, Stellung der Exjesuiten, 182-85; Steinmayr, "Geschichte der Universitätssternwarte," 267-70.

5 See Joseph Feil, Zur Gründung einer Akademie der Wissenschaften unter Maria Theresia (Vienna: Gerold, 1860).

6 Hviid, Andreas Christian Hviids Europa, 370 (entry on November 21, 1778). 
"historical-philosophical" one. The academy, von Hess argued, ought to be financed either by issuing calendars, or by imposing a nationwide tax on the book trade. Hell's proposal ${ }^{7}$ was more modest in scientific terms but seemingly more detailed with regard to financial planning. He argued that the Viennese academy, like its older sisters in London and Paris, ought to focus on "physikalisch-mathematische" disciplines—astronomy, geometry, mechanics, physics, botany, anatomy, and chemistry - only. Hell established this proposition on epistemological and methodological grounds. The goal of a learned society is "the elevation of the sciences on a higher level; and the society achieves this goal by new findings and discoveries, which do not yet exist, in the sciences" by the application of the spirit of observation and invention that imbues men of science. ${ }^{8}$ Fields of learning that, in the strict sense, are not suitable for making such new discoveries - like theology and metaphysics (Hell is emphatic about the need for a sharp distinction between knowledge and faith), as well as the arts and antiquarian studies-should not be mingled in the academy, and if they are to be organized in a learned society at all, it ought to be a separate one. Hell asked rhetorically:

Should the refined mind, that possesses no knowledge in mathematics, physics, astronomy, mechanics etc., follow lectures and profound demonstrations, watch subtle experiments, formulate judgments on these, of which he understands nothing and grasps nothing, and which have no influence on his field, nor any use for it; and similarly, should the profound astronomer, mathematician, geometer, physicist admire and appreciate the fine essays on the improvement of the German language, orthography, poetry, and theater? ${ }^{9}$

Besides the thematic focus, Hell also pressed for following the London and Paris models in the ethos of sociability as the basis of the convening and the operation of the academy as a "friendly association of a few men of superior learning" who "assemble voluntarily as friends thanks to their harmony of temper." At first sight, this closely resembles the enlightened values cherished

7 The full text of Maximilian Hell, "Patriotischer Plan einer Kayserlich-Königlichen zu Wienn errichtenden gelehrten Gesellschaft, oder Academie der Wissenschaften" is available in Hans Schlitter, Gründung der kaiserlichen Akademie der Wissenschaften: Ein Beitrag zur Geschichte der vormärzlichen Österreich (Vienna: Hölder, 1921), 66-112. Excerpts (the substantive parts, without the lengthy sections on organization and procedure) have been published in Lengyel and Tüskés, Learned Societies, $67-75$.

8 Lengyel and Tüskés, Learned Societies, 68.

9 Lengyel and Tüskés, Learned Societies, 69-70. 
(though not always practiced) in the Republic of Letters. More pragmatically and likely, it may have been intended as an "early warning" that, just as a decade earlier, Hell would not welcome any attempt by the government to appoint academicians at will: "From this, it is clear why sovereigns who established a learned society in their states and took it in their high protection, themselves made it a rule not to harm the free election of members, and refrained from nominating any new member without the voluntary consent of the society." ${ }^{10}$ Finally, the repeated emphasis on the personal bond and esprit de corps in the proposal_-"friend," "friendship" appears no fewer than eight times in the three paragraphs explaining what a scientific society is-also prepares the ground for Hell's own recruitment strategy, targeting kindred spirits. Half of the proposed salaried members (initially, there were to be only six of them-in the longer run, Hell planned three in each of the seven classes, plus two secretaries and a treasurer) were ex-Jesuits: besides Hell himself, Scherffer and Pál Makó (1723-93), a professor of mathematics and philosophy from the Theresianum. The most prominent of the non-Jesuits was the professor of chemistry and botany and director of the Viennese botanical gardens, von Jacquin. The team also included the court mathematician, Joseph Nagel (1717-95), and the military engineer and general Leopold Freiherr von Unterbergen (1736-1819).

Hell devised a complex financial model to support the academy. Some of the money was to emerge from the so-called Jesuit fund (Jesuitenfond) created from the income of the confiscated Jesuit property, and a portion of the profit from the sales of the newspaper Wienerisches Diarium was also to be turned to the noble end. Additional money was promised by the Kingdom of Hungary, on condition that one-third of the members of the academy were to be Hungarians and half of these Protestants. However, Hell hoped to raise the bulk of the funding from what would have amounted to a complete reform of the production and dissemination of calendars. Calendars were big business in the period, provided one had the means of buying from the state a privilege to issue one and having it renewed at ten-year intervals. Hell now proposed the elimination of the existing system, and the establishment of a CalenderAdministrations-Collegium out of the members of the academy, with himself as the collegium's director. This would have ensured expert overseeing of the contents of the calendars - so that instead of a store of idle telltale and superstitious beliefs, they could become a means of disseminating useful knowledge, a goal that resonates with the instruction for the imperial and royal astronomer issued nearly two decades earlier. Besides, through the collection

$10 \quad$ Lengyel and Tüskés, Learned Societies, 68. 
of a "calendar tariff" in exchange for this service, the academy would have made a hefty income. ${ }^{11}$ This deal would not have been unique in eighteenthcentury Europe: in Sweden, Hell's colleagues had secured income for the Academy of Sciences in Stockholm in exactly the same manner. ${ }^{12}$

The first and the second source initially seemed rather unproblematic, whereas the Hungarian proposal was in any case insufficient to finance the entire project. It was the third and most substantial source of income that in the end toppled the entire project. The government committee on academic affairs (Studien-Hof-Commission) ${ }^{13}$ discussed the matter on November 14, 1774, and four days later a calendar privilege was issued for the academy. ${ }^{14} \mathrm{Al}-$ ready in the same year, Hell published his first German-language calendar, and soon he produced others: an almanac for the knightly order, a Physikalischer Almanach (Physical almanac), a chronological almanac, an almanac for children, and an almanac with riddles. ${ }^{15}$ Hell also informed the public about the expected benefits of the scheme in announcements in the Viennese newspapers, using his new official title. ${ }^{16}$ There were thus hopes that the proposed scheme would be adopted, but the optimism soon began to subside. While provincial authorities were instructed to make sure that upon the expiry of existing calendar privileges their publishers stop issuing them, they were also requested reports on the print-run and pricing of existing calendars. From the responses, Hell calculated that the predictable income was substantially short of what had been expected:17 twenty-four to twenty-six thousand florins, while

11 A large number of documents have been preserved among the holdings of the Österreichisches Haus-, Hof- und Staatsarchiv. Allgemeines Verwaltungsarchiv (HHStA AVA). Studienhofkommission. 75: Wien Akademie der Wissenschaften (Sig. 15); 132: Protokolle der Studienhofkommission (Sig. 28.)

12 Lindroth, Vetenskapsakademiens Historia, 1:1, 102-10.

13 The committee at this time consisted, among others, of long-standing and experienced servants of the Theresan reforms, such as Kollár and law professor Martini, as well as more recent recruits like Rautenstrauch—but also Ignaz Müller, by now dismissed as the confessor of the empress and an ex-Jesuit, but still the abbot of the prestigious Viennese Stift St. Dorothea.

14 For the protocols, HHStA AVA Studienhofkommission, 132. Sig. 28. fols. 724-25; 75. For the privilege, Sig. 15. Akademie. Kalenderwesen 1774-1776: 1775. No. 2, fols. 1-2. "Privilegium impressorium privativum für die [...] Akademie der Wissenschaften auf alle Kalender."

15 Sommervogel, "Hell," 256. On the encompassing meaning of "physical," see above, 321.

16 See, e.g., $W D$, no. 92 (November 18, 1775): 8 .

17 The reason for this was the amount of state duties included in the price of almanacs. Hell requested exemption from these duties. He, however, never requested "to be relieved of responsibility" as claimed in the introduction to the publication of the academy plan in Lengyel and Tüskés, Learned Societies, 67. 
the academies of Paris, London, and Berlin were maintained from about twice as much.

The other difficulty was that the whole scheme implied a deep conflict of interest between Hell as the future "director of calendar issues" and the man on whom the continuous publication of the Ephemerides depended: court publisher and printer Johann Thomas von Trattner (1717-98), who made fortunes on the lucrative trade in calendars. Von Trattner, arguably the most successful book-dealer of the time in Austria, ${ }^{18}$ seems to have spared no effort to ruin the financial scheme, and by implication the academy project. One of his strategies was to annoy Hell by delaying the delivery of the 1775 volume of the Ephemerides. In a letter to Weiss, Hell felt the need to thus apologize and avert the responsibility:

The Ephemerides, which were finished at the end of the year, I have not yet been able to acquire from Trattner despite repeated requests. I suspect that he has deliberately chosen to cause me this bother because he has learned of the imperial decree, by which all the calendars that used to be printed throughout the hereditary lands have now been earmarked to finance the academy of sciences that is to be established here in Vienna. In this way, he has been bereaved of an income of thousands of florins. As soon as I receive these Ephemerides, I will send a copy to my Highly Honorable Mister Colleague [i.e., Weiss] in Trnava. ${ }^{19}$

Trattner did not stop there. During an audience, he "moaned and begged" the empress to revise the plans, unless she wanted to send him, together with his creditors, to bankruptcy. ${ }^{20}$ This story is confirmed by a Danish theology student, Andreas Christian Hviid (1749-88), who visited Vienna from October 27, 1778 to January 20, 1779 with the aim of transcribing ancient manuscripts. His travel diary is crammed with detailed information not only on archives and libraries but also on the intellectual elite of the Habsburg capital. Hviid met Hell on several occasions, both in the home of the highly sociable papal nuncio Giuseppe Garampi (1725-92) and in the observatory. Despite their diverging views on religion and politics-Hviid was a Protestant and highly supportive of Enlightenment ideas-he describes Hell in sympathetic terms. Hviid was

18 See, e.g., Peter R. Frank and Johannes Frimmel, Buchwesen in Wien 1750-1850: Kommentiertes Verzeichnis der Buchdrucker, Buchhändler und Verleger (Wiesbaden: Harrassowitz Verlag, 2008), 198-200.

19 Hell to Weiss, January 27, 1775, in Pinzger, Hell Miksa, 2:118.

20 Feil, Versuche, 65. 
allowed to look through Hell's works in progress on the Expeditio litteraria and heard him praise Danish science. An entry in the diary also includes a rumor on the failed efforts to establish an academy of sciences in Vienna:

Professor ... tells me that Hell a few years ago was given orders to draw up a plan for the establishment of an academy of sciences in Vienna. In it, physics, astronomy, and mathematics were to be included, just like in the English and French academies. He did draw up this plan, and suggested for the funds of the society the income from the almanacs, which in the first year probably had run to some forty thousand Reichstaler, but which would possibly increase to an annual eighty-eight thousand in the future. A publisher named Trattner was publishing the almanacs of the entire monarchy. He had access to the empress, and having heard rumors of the society, he demanded an audience at her place. Upon entering the chamber, he fell to his knees before the portrait of Emperor Francis, which was hanging there on the wall, wailed to it as if to the living emperor, telling him that he was going to lose his monopoly and all his income be diverted for physics and heresy. The empress thereupon rejected Hell's plan. ${ }^{21}$

"On the other hand," Hviid presumes that "there may have been a hint of Jesuitism involved. For if the first members of the academy came from that company, then the rest were likely to be selected from the same regiment as well." ${ }^{22}$ Following Hviid, one may interpret Hell's plan of ${ }^{1774-75}$ as, at least in part, an attempt to retain the Jesuit heritage. In his letters to Bernoulli and Weiss from this period, ${ }^{23}$ Hell emphasizes that a part of the funds of the academy were to be used to preserve the Jesuit observatories in Graz, Vienna, and Prague, whose directors were going to be members of the academy as well.

If there was, as seems to have been the case, a Jesuit bias in Hell's academy project, it did not escape the attention of the highest decision-maker. True, throughout the autumn of 1775 , Hell still maintained steady communication with the chancellery on the subject of the calendar, and the plan of setting up the Calender-Administrations-Collegium was on the agenda of the StudienHof-Commission as late as in April 1776. The committee took pains to find

21 Hviid, Hviids Europa, 370 (entry on November 21, 1778). The manuscript version of Hviid's diary has not survived. Several names of persons are deliberately left out in the published version of 1787 , as here. See the introduction of Michael Harbsmeier and Morten Petersen to the annotated edition referred to here.

22 Hviid, Hviids Europa, 370 (entry on November 21, 1778).

23 Hell to Bernoulli in Berlin, dated Vienna, March 1, 1775 (Uвв); Hell to Weiss in Trnava, dated Vienna, January 27, 1775 (Vargha priv.). 
alternative sources of funding, but ultimately all this was to no avail. Already in a note on a memorandum of the committee of November 25 , 1775, Maria Theresa seems to have made up her mind on the matter. A reference to the "poor bookkeepers and bookbinders" and the stress of the need to raise funds "without oppressing the citizens" gives the impression that her heart had indeed been softened by von Trattner's appeals. However, she also adds that she

couldn't possibly decide to launch an accademie des scienses [sic] with three ex-Jesuits and a professor of chemistry, however worthy, we should be a laughing-stock in the world [...]. The accademie [...] should present a regular plan on how, and what subjects and objects, this accademie would treat with benefit and honor. I find the Abbé Hell not strong enough, an accademie that is worse than the already existing ones would be worth neither the costs nor the effort. ${ }^{24}$

Despite the comment on Hell's qualities, Maria Theresa's fulmination should not be taken as an expression of contempt for Jesuits or Jesuit science, but rather as a sober acknowledgment that soon after the suppression of the Society of Jesus, establishing an academy effectively under Jesuit control would be a strange and inconsistent step. From Hell's point of view, the result was all the same: there was to be no Austrian Academy of Sciences. The empress renewed the patents of the principal book dealers, among them the prosperous von Trattner. Hell was at the same time allowed to publish his own calendars.

The empress's words show that besides the embitterment of a representative of powerful commercial interests in the realm, the ruler's decision to abandon the project of the academy was also motivated by considerations that had to do with the substance of the enterprise. Ever since Hell had arrived in Vienna in 1755, he had felt the unfailing support of Viennese officialdom for his projects. The outcome of the strenuous efforts he was making over two and a half years to establish an academy of sciences - which, from his perspective, may indeed have been an antidote to the blow that Jesuit learning had suffered as a result of the suppression-demonstrated that such support was no longer unequivocal and to be taken for granted. The special relationship with the court and the dynasty became broken.

Even among such circumstances, Hell's personal merits, and the scientific contribution and representational value of his institution, continued to be acknowledged and utilized. A case in point is a highly important diplomatic visit

24 HHStA AVA Studienhofkommission, 75. Sig. 15. Akad. d. bildenden Künste. 1775: 3007. fol. $10^{\mathrm{v}}$. Cf. Feil, Versuche, 64; Evans, Austria, Hungary, and the Habsburgs, $5^{0 .}$ 
in Vienna by Grand Duke Paul of Russia (1754-1801, r. as tsar 1796-1801) along with his duchess Sophia Dorothea of Württemberg (in Russia re-named Maria Feodorovna [1759-1828]), as well as the duke of Württemberg and his family, at the turn of $1781-82 .{ }^{25}$ The high stake for Joseph II was to detach these realms and dynasties from their Prussian sympathies, and one of the means was to arrange the marriage of a niece of Charles Eugene of Württemberg (1728-93, r.1737-93), Elisabeth (1767-9o), to Joseph's nephew Francis (17681835, r.1792-1835) who — as the emperor lacked a male heir — by this time was a long-term candidate for the imperial throne. Accordingly - and contrary to Joseph's character and inclinations-lavish entertainment was carefully designed, with feasts, balls and outings, visits to the imperial collections, opera performances, a demonstration of Farkas (Wolfgang von) Kempelen's (17341804) famous chess-playing machine, and a piano competition between Mozart and the Italian musician and composer Muzio Clementi (1752-1832). Besides these attractions, the program included two visits to the university: a formal one at the university's annual celebration on the day of Immaculate Conception, and an informal one, on December 15, 1781, to the observatory. Hell showed the guests around and gave them an account of the "Lapland expedition," whereupon "His Majesty deigned to take the place of the teacher and, to the admiration of all, described the many instruments there, particularly the meridian line, and the use of those that H.M. had brought to the observatory from the museum of prince Charles of Lorraine."26 Despite such occasional honors, the fate of the academy plans showed that Hell's scope of action on the institutional front had narrowed in the capital, while he was also becoming one of many respected but equal agents on a public scene that had its own rules of emulation, competition, recognition, and conflict resolution. This is also how he is recorded by the enthusiastic portraitist of that scenefrom academic and polite sociability and literary life, through manners and morals, to hygiene and crime, and many more - writer and librarian Johann Pezzl (1756-1823) in his "sketches of Vienna": as one of the remaining former Jesuit savants still capable of enhancing the renown of the university. ${ }^{27}$

One of the developments on that scene that Hell followed with a blend of dismay, consternation, and accommodation was the spread of German and the shrinking space for Latin. As a Hungarus, he wished to see Latin prevail as the lingua franca of his multi-ethnic fatherland. As a partisan of the Catholic Church, he savored a glorious past in which there existed a single, universal

25 For a detailed account of this episode, see Beales, Joseph II, 2:126-32.

26 Beales, Joseph II, 2:131. Cf. Wiener Zeitung, no. 101 (December 19, 1787): 10.

27 Johann Pezzl, Skizze von Wien (Vienna: Krauss, 1787), 5:746. 
language for the servants of God. As a representative of the Republic of Letters, he saw the benefits of Latin for communication across linguistic and political barriers. Thus, in his arguments for the preservation (or restoration) of Latin, his old loyalties ran together, and while his mother tongue was German, he saw little benefit of it within this matrix. For pragmatic purposes, back in the early 176os he explained to Bishop Eszterházy that if there was any modern vernacular Balajthi ought to master when the latter came to study with him in Vienna, it was French, "which is of utmost importance for a mathematician." ${ }^{28}$ A good decade later, Hell reported that Madarassy was learning French with ease, but struggled to make progress with German. In the end, Madarassy asked the bishop for money to move out of Hell's apartment and hire a room in a private home, so that he could speak the language on a daily basis. ${ }^{29}$ Hell did not oppose this, which may be taken as an indication that he was beginning to understand the voice of the times, and the stakes of listening to it. Privately, he still continued to express his reservations about the use of modern vernaculars in learned communication. As Hviid reported in 1778, Hell told him: "Danes always wrote in Danish; this was an impediment to our scientific image abroad [...]. We [i.e., the Danes] should write more in Latin, he argued, or at least in French, which is also a universal language." ${ }^{30}$ Hell did so despite the fact that his own knowledge of French, as we learn from Hviid, was passive: during dinners at Garampi's, he spoke "kitchen Latin" only, and that "in an unusual rapidity," since "this erudite does not speak French." ${ }^{31}$ Even as late as the early 179os, in a particularly long and bitter letter to the bishop of Eger, Hell lamented over the dissolution of the Society of Jesus, and what he called the "seminars of Antichrist" (seminaria Antichristi) that had replaced the theology studies at the university since the Jesuit professors were removed from their posts. As a result of the implementation of compulsory teaching in German, knowledge of Latin had seen such a rapid decline among university students that even Mass at the university church was now held in the vernacular. As a result, young women attended, and flirted overtly with the students. The fair sex would not have been present, Hell argues, if only the Masses had been celebrated in Latin as they used to be in the good old days before the suppression of the Society of Jesus:

28 Hell to Eszterházy in Eger, dated Vienna, October 24, 1762, FLE, AV 2629.

29 Hell to Eszterházy in Eger, dated Vienna, August 22, 1775 and July 1, 1776; Madarassy to Eszterházy, dated Vienna, April 2, 1776, FLE, AV 2629.

30 Hviid, Hviids Europa, 369 (entry on November 21, 1778).

31 Hviid, Hviids Europa, 401-2 (entry on December 6, 1778). 
After the discontinuation of the congregations of Mary, which had been introduced by the Society [of Jesus] and which offered schooling in true Christian virtues and morals, there were no exhortations pro majoribus until the present year, when such were finally ordered to be held on every Sunday in the university church, but for no more than half an hour, and not aimed at the students, since few of them show up anyway. Instead, they are aimed at women, who occupy the better part of the church, not without scandal, dressed as they are for the seduction of the youth, attracting the gaze of the youngsters by nodding and gesticulating, etc. The cause of this evil is the German language [...]; in case the sermons had been in Latin as they ought to [...], the female sex, ignorant of the Latin tongue as she is, would never have entered the university church at all. ${ }^{32}$

These grumblings of the old man notwithstanding, one cannot help observing that after the suppression of the Society of Jesus, Hell published in German quite extensively and regularly. His issuing of German-language almanacs around 1775 has already been mentioned. In the same period, he also published numerous articles in German-language newspapers, journals, and books. When in 1775 a collection of essays by ex-Jesuit professors, entitled Contributions to Various Sciences by a Few Austrian Erudites, ${ }^{33}$ was issued in Vienna, Hell apparently welcomed the German rendition of some selected astronomical works of his. After all, his two pieces in this volume had already been published in Latin in the appendices of the Ephemerides. Toward the end of his life, at the very same time that he bewailed the widespread decline of proficiency in Latin to Eszterházy, he allowed a colleague in Wrocław, Anton L. Jungnitz, to translate nearly all the appendices of his Ephemerides into German and publish them in quick succession, as Contributions to Practical Astronomy, in the Form of Various Observations, Treatises, and Methods Taken from the Astronomical Ephemeris of Mr. Abbé Maximilian Hell. ${ }^{34}$ Hell also discussed astronomy in ordinary newspapers. One increasingly verbose series of articles were published in the Mannheimer Zeitung (Mannheim newspaper) and the Wienerisches Diarium in late 1777 . Here, two ex-Jesuit astronomers, Mayer and Hell, engaged in

\footnotetext{
32 Hell to Eszterházy in Eger, dated Vienna, November 11, 1791, FLE, AV 2629.

33 Karl Scherffer et al., Beyträge zu verschiedenen Wissenschaften von einigen Oesterreichischen Gelehrten (Vienna: Augustin Bernhardi, 1775).

34 Maximilian Hell, Beyträge zur Praktischen Astronomie, in verschiedenen Beobachtungen, Abhandlungen, Methoden aus den astronomischen Ephemeriden der Herrn Abbe' Maximilian Hell, trans. and ed. A. [Anton] L. Jungnitz (Breslau: Korn, 1790-93). In 1789, Jungnitz had already published a German translation of Hell's proposal of new constellations in honor of King George III and William Herschel (Vienna: Trattner, 1789).
} 
a discussion of the phenomenon that is nowadays known as double stars. ${ }^{35}$ Hell asserted-in response to inquiries from "partly learned, partly curious men" - first, that while on the basis of observations of "satellites around fixed stars" earlier in 1777, Mayer claimed to have discovered a new phenomenon, it had in fact been known at least since the times of Tycho Brahe, as Hell himself had mentioned in a report to the Parisian academy in 1759 . What is more, he disagreed with Mayer in his interpretation of the phenomena as "satellites" (Fixsterntrabanten, Nebenplaneten) and claimed that they were in fact small stars themselves, only seeming to be planets because of their vicinity to larger ones. ${ }^{36}$ An anonymously published response in the Mannheimer Zeitung called Hell an "unashamed liar" unable to prove his points, and the court astronomer replied in kind: as the author "has revealed his unbearable ignorance, I must deal with him as a teacher with a pupil, and first refer him to a book that every student of astronomy must have in his hand"-namely Lalande's 1771 textbook. ${ }^{37}$ Mayer continued publishing (and debating) on the phenomenon in both German and Latin, whereas Hell appears to have withdrawn from the public debate.

In the same year as the controversy over double stars, Hell even had a short spell as an outright popularizer of science in the vernacular, in contributions to the Viennese Realzeitung. ${ }^{38}$ In the third issue of 1777 , the editors announced that from then on, the famous court astronomer would give regular accounts of celestial occurrences, meteorological observations, and other "astronomical news" for those interested in the subject. Hell himself went on to explain that

as our annual Ephemerides are only accessible to those lovers of astronomy who are proficient in Latin, and there are still many lovers of astronomy among our learned German nation who spend their spare time pleasantly and usefully with astronomical observations: so we flatter ourselves that we render a welcome service by the monthly publication of a very brief excerpt [on the above topics]. ${ }^{39}$

35 For an excellent analysis of the polemics surrounding Mayer's work on double stars, see Moutchnik, Forschung und Lehre, 273-314. For minor corrections, see, however, Aspaas, "Review of Moutchnik." Hell already gave notice to the public about Mayer's observations in the summer of 1777 , publishing excerpts from a letter to him by the Berlin astronomer Bode, in which they are mentioned. Realzeitung, no. 18 (July 29, 1777): 284-85.

$36 \quad W D$, no. 90 (November 8, 1777): 4-5.

37 Mannheimer Zeitung, nos. 93 and 94 (November 20 and 24, 1777); WD, no. 99 (December 10, 1777): 9-10.

38 Cf. Haberzettl, Stellung der Exjesuiten, 31-32.

39 "Astronomische Nachrichten," Realzeitung, no. 3 (January 14, 1777): 44-45. 
Hell conscientiously published the monthly reports up to November 1777, when he broke with the journal. As he explained early in the following year in the Wienerisches Diarium, this was because "the new authors of this journal have chosen a new plan," namely not to publish anything already available in other Viennese publications. He also announced that the same kinds of reports would from then on be published in the Wienerisches Diarium, ${ }^{40}$ and the first of these indeed followed right upon the heels of the announcement. For their part, the editors of the Realzeitung hastened to clarify that Hell's reports had "hardly anything attractive" to offer ${ }^{41}$ Hell's justification of his decision may well have been a polite veil over his discomfort with the editorial line of the journal in a broader sense: during the following years-no doubt thanks to the influence of von Born, who appeared among its authors in the same year as Hell, and writer Alois Blumauer (1755-98), who became its editor in 1782 - the Realzeitung was taking an ever more radically enlightened turn, with freemasonry becoming its leading source of inspiration.

Before considering the open attack on Hell by von Born a few years later, we should look at the polemics in which the court astronomer was thrown by his ventures into discussing some of the great medical issues of the times. In the 1777 Realzeitung, besides the astronomical reports and a brief essay on antidotes against bedbugs, Hell also published an article on the use of sugar as prophylactic medicine against scurvy. ${ }^{42}$ While in Vardø, Hell had experienced that several local inhabitants, particularly seafarers, suffered from this disease. Its cause, Hell argued, was the consumption of too much smoked meat, but especially the high salt content of the air. He claims to have recalled from his studies that sugar - "a kind of vegetable-based salt"- has the capacity of neutralizing the effect of salt, therefore he instructed their cook to salt meals very lightly, but use generous quantities of sugar (with which, thanks to the fact that there was a sugar refinery in Trondheim, they were well equipped). As a result, he and his team could avoid the disease without a single exception. For someone as proud as Hell was of his credentials as a scientist with scrupulous standards of verification, he took this perhaps too lightly as a proof of the preventive powers of sugar, yet he even risked a hint that it might be suitable for healing patients already suffering from scurvy, and closed with a passing reference to the possibility of similar benefits from the consumption of horseradish

$40 \quad W D$, no. 3. (January 10, 1778): 10.

41 Realzeitung, no. 3 (January 20, 1778): 49.

42 For the discussion of bedbugs, see Realzeitung, no. 7 (May 13, 1777): 107-11; on scurvy, Realzeitung, no. 8 (February 18, 1777): 122-26. 
and sauerkraut. ${ }^{43}$ The essay was reissued in 1779 , along with a devastating refutation based on the components of sugar set against the (presumed) causes of scurvy, by a certain Dr. von Albertiz. ${ }^{4}$

By far more intriguing and important than Hell's speculation on sugar as an antidote to scurvy was Hell's other foray into the life sciences: his engagement with magnetic healing in general, and specifically the individual primarily associated with this practice during the Enlightenment, Franz Anton Mesmer. Before becoming a celebrity in Paris after his arrival there in $1778,{ }^{45}$ Mesmer had spent nearly two decades of his life in Vienna where, in turn, he had come to study medicine in 1759 after disillusioning experiences at the Jesuit universities of Dillingen and Ingolstadt. Mesmer, a student of the Dutch director of the Viennese general hospital, Anton de Haen (1704-76), who inoculated him with an enthusiasm about British experimental medicine, defended and published his dissertation entitled De planetarum influxu in corpus humanum (On the influence of the planets on the human body) in 1766. In substantial parts plagiarized from a 1704 work by the London physician Richard Mead (1673-1754), Mesmer's essay still put forward a new theory: instead of an influence of gravity acting on the body through the mediation of air and cognate fluids as providential agents, it posited an immediate force named "animal gravity," which "intensifies, remits, and agitates cohesion, elasticity, irritability, magnetism, and electricity." While the cosmos, as well as the animal body, is normally

43 Hell demonstrated no awareness of the widespread preoccupation with combating scurvy in his age, including the work of the Edinburgh naval surgeon James Lind (1716-94) a generation earlier, or the highly successful "regiment of cleanliness, fresh air, and diet" implemented on his voyages by James Cook, for which he was awarded a medal of the Royal Society the year before Hell wrote his short essay. Cf. Stephen R. Bown, Scurvy: How a Surgeon, a Mariner, and a Gentleman Solved the Greatest Medical Mystery of the Age of Sail (New York: Thomas Dunne/St. Martin's Press, 2003).

44 Der Zucker, ein neues Präservativmittel wider den Scorbut (Scharbock) von Herrn Abt Kaiserl. Königl. Hofastronom in Wien, Nebst einer Zuschrift, darinn des Scharbocks Ursachen etc. und auch des Zuckers eigenschaften gründlicher erwogen und widerlegt werden von Herrn von Albertiz, der Arzneygelartheit Doktor (Vienna: Johann Friedrich Jahn, 1779). See also Aspaas, "Hell og Sajnovics," 65.

45 Most of the literature on Mesmer is focused on his Parisian years where "mesmerism" blossomed, discussing the "early years" in Vienna from the perspective of the "denouement." The most compelling treatment from a historical perspective is still Robert Darnton, Mesmerism and the End of the Enlightenment in France (Cambridge, MA: Harvard University Press, 1968). More recently, see (despite the error of believing Mesmer to have been a native of Vienna, 199) Jessica Riskin, Science in the Age of Sensibility: The Sentimental Empiricists of the French Enlightenment (Chicago: University of Chicago Press, 2002), 189-226. On Mesmer in the context of the "invention of celebrity," see Antoine Lilti, Figures publiques: L'invention de la célébrité 1750-1850 (Paris: Fayard, 2014), 86, 89. 
characterized by harmony among these features, disturbances may arise, which can be counteracted by expert resort to "universal attraction, animal gravity, or animal magnetism [the existence of magnetic fluids in all bodies]," as Mesmer was subsequently to claim. ${ }^{46}$

Even while in Vienna, Mesmer became gradually aware of the public appeal and commercial potential of the implications of these ideas, apparently adumbrating novel ways of resolving the ancient problem of restoring harmony between the cosmos and the human body by resorting to the new science. Though on a lesser scale than in London or Paris, the eighteenth century was the first great age of popular science in Vienna, too, with regular reports in the pressbesides those mentioned, only Hell himself contributed many dozens of brief accounts and explanations on a wide range of topics from eclipses through "northern lights" to earthquakes-public lectures, demonstrations, and experiments. Especially captivating was the contemplation of the invisible forces of nature surrounding the inhabitants of the world of Enlightenment: gravity and electricity, fluids and gases, capable of being harnessed to applications from lifting man in the air to curing bodily disorders. Mesmer-characterized as offering a caricature of empiricist natural science by "magnifying $[\ldots]$ the elevation of feeling as the ultimate arbiter of truth" 47 -launched a medical practice in Vienna soon after the publication of his thesis. For several years, however, his approach to medicine seems to have remained "basically orthodox,"48 and he earned prosperity and social standing mainly thanks to marrying a wealthy widow in 1768. It was in $1774-75$ that he first treated a patient-a Miss Franziska Österlin, suffering from hysteria - with magnetized steel attached to her feet and heart, with dubious results. He then managed to obtain testimonials of successful treatment from several prominent individuals, but as these failed to obtain him public recognition among both physicians and academicians (he was even denounced as a fraud by Van Swieten's successor as court physician, Jan Ingenhousz [1730-99]), Mesmer decided on the "therapeutic gamble" of curing a blind pianist, Maria Theresia Paradis $(1759-1824) \cdot{ }^{49}$ It was the

46 George J. Bloch, ed., Mesmerism: A Translation of the Original Medical and Scientific Writings of F. A. Mesmer (Los Altos: W. Kaufmann, 1980), 14-20, cited in Simon Schaffer, "The Astrological Roots of Mesmerism," Studies in History and Philosophy of Biological and Biomedical Sciences 41 (2010): 158-68, here 160. Mesmer did not, however, use the term "animal magnetism" until 1775, see below.

47 Riskin, Science in the Age of Sensibility, 191.

48 Douglas Lanska and Joseph T. Lanska, "Franz Anton Mesmer and the Rise and Fall of Animal Magnetism," in Brain, Mind and Medicine, ed. Harry A. Whitaker, Christopher Upham Murray Smith, and Stanley Finger (New York: Springer-Verlag, 2007), 301-20, here 302.

Lanska and Lanska, "Franz Anton Mesmer," 303-5. 
failure of this much-publicized venture that discredited Mesmer in Vienna and compelled him to leave for Paris in January 1778.

Hell's point of entry in this story is that - just like he had received the first magnets he used in his experiments in Cluj in the 1750 s from a counterpart of his at the Calvinist college-he supplied the magnets that Mesmer used in the attempted treatment of Miss Österlin. We have seen that, on the side of his chief preoccupations, magnetic healing was a lasting interest of Hell, and even in June 1774 he apparently alleviated the suffering of a baroness from severe abdominal pain by lending her magnets. This is related by Hell in a small pamphlet published at the very beginning of 1775 , in which he also clarifies that from the patient's account of her feelings he had concluded that the magnets exerted their effect through the nervous system. ${ }^{50}$ At the same time, he stressed — at this point, seemingly out of sheer modesty — that while he triggered Mesmer's as yet apparently successful work with Miss Österlin by supplying him with magnets, he himself did not participate in the treatment in either this case or in similar others. Just one day later, on January 5 , 1775, Mesmer published his letter to the Altona physician Johann Christoph Unzer (1747-1809), in which he introduced the notion of "animal magnetism," attributing the healing effect not to the steel magnets used but to the magnetism in the physician's body, capable of channeling the invisible magnetic fluids that pervade the universe into the organism of the patient in order to restore its balance. Mesmer also projected this idea back into the 1766 dissertation. 51 " Just as the Sun and the moon, in their various positions vis-à-vis one another and the Earth and its distance, determine the periods of ebb and flow in the sea and the whole atmosphere, I demonstrated that a similar ebb and flow arises from the ordinary causes in the human body."52

It was on the basis of such parallels that Mesmer even claimed that "animal magnetism is a reconciliation of two known sciences, astronomy and

5o Maximilian Hell, Unparteyisher Bericht der in Wien gemachten Entdeckungen der sonderbaren Wirkungen der künstlichen Stahlmagneten in verschiedenen Nervenkrankheiten (Vienna: n.p., 1775), republished in Sammlung der gedruckten und geschriebenen Nachrichten von Magnet-Curen, vorzüglich der Mesmerischen (Leipzig: Hilschern, 1778), 11-12. The same collection begins with a brief, anonymous account of similar healings by Hell (see 1-3).

51 Franz Anton Mesmer, Schreiben [über die Magnetkurvon Herrn A. Mesmer, Doktor der Arzneygelahrtheit], an einen auswärtigen Arzt (Vienna: Kurzböck, 1775), republished in Sammlung der gedruckten und geschriebenen Nachrichten, 16-25, published in English in Bloch, Mesmerism, 23-30. 
medicine,"53 which would have been one more reason for him to expect that Hell—whom he continued to mention with gratitude and respect-would be a long-term partner in his ventures. It may have been known to Mesmer that on his celebrated astronomical expedition Hell and his associates also carried out geomagnetic observations and tackled issues like diurnal variation, magnetic storms, and northern lights (though Hell's vigorous refutation of contemporary suggestions of a relatedness between the latter two phenomena was published in the Ephemerides of the following year).${ }^{54} \mathrm{It}$ is small wonder that he was baffled when Hell, in another quick response, effectively disavowed him- "I could hardly have suspected that in his letter Dr. Mesmer would call me an eyewitness of certain experiments unknown to me"-and went on to elaborate on his firm conviction that the therapies worked because of physical magnetism, not cosmic harmony. ${ }^{55}$ In fact, this was more than he was willing to acknowledge earlier. Despite his attempts at the medical use of magnets in both Cluj in the 1750s and Vienna in the 1760s, none of the editions of Hell's treatise on the application of steel magnets contained any mention of such uses, and in a 1765 letter to Weiss he was expressly skeptical about the possible healing power of his magnets:

I am happy that my Father Colleague [i.e., Weiss] has become a colleague of mine even in medical subjects. For even I have here turned a magnetic doctor and experienced the effect [of magnets] on various persons. However, the effect of this artificial magnet in easing the pain of toothache, I ascribe not to magnetism (which can have no influence on the teeth unless these were made of iron or steel), but to the coldness of the steel. Next time I will test this with a piece of steel that is not magnetized, and I think the effect will be the same; my Honorable Father Colleague can make the same experiment, pretending that the metal that is applied is magnetic, so that the pain of the patient is not disturbed by persuasion. ${ }^{56}$

53 Franz Anton Mesmer, Mémoire sur la découverte du magnétisme animal (1779), in F.-A. Mesmer, Le magnétisme animal, ed. Robert Amadou (Paris: Payot, 1971), 93. Cf. Schaffer, "Astrological Roots of Mesmerism," 160.

54 Hell, Theoria nova. Cf. Aspaas and Lynne Hansen, "Geomagnetism by the North Pole."

55 Maximilian Hell, Schreiben über die allhier in Wien entdeckte Magnetencur, an einer seiner Freunde (Vienna, January 12, 1775), in Sammlung der gedruckten und geschriebenen Nachrichten, 26 and passim.

56 Hell to Weiss in Trnava, dated Vienna, May 7, 1765. Pinzger, Hell Miksa, 2:198. The reference to Weiss's activities as a healer is obscure. 
What Hell's unfolding conflict with Mesmer illustrates is that while he was aware of the emergence of vitalistic theories and the related scientific practices, he viewed them with suspicion and remained an inveterate mechanist. He even looked down on Mesmer's experimentations with the same kind of contempt he had toward the lack of "exactitude" he supposed to have diagnosed in Pray's linguistic work. The remarkable blend of bursting into a field of knowledge beyond his own specialization and behaving provocatively—again, just like in the case of language and history, but this time before the eye of the public - may also have been a product of the disaffection, anxiety, and insecurity Hell presumably felt during the immediate post-suppression years, as well as the perceived need to prove himself an all-round scholar worthy of leading an academy of sciences. A final interesting point is Hell's hint to Weiss that in order to attain the desired therapeutic results, it might be sufficient to pretend that the metal is magnetized. In a very rudimentary form, this seems to anticipate the position of the experts employed in the famous 1784 investigation of mesmerism in Paris (itself echoing an important strain in eighteenth-century thought): that even in the absence of any alleged "magnetic fluids" (or magnetized metal), the imagination is capable of having dramatic effects on the body - that belief in the curative effect is almost the cure itself. ${ }^{57}$

An astonished Mesmer gave vent to his frustration over Hell's sudden change of heart in writing, to which Hell replied in kind, but in the end he assured the readers that all "misunderstandings" between the two of them had been clarified, and reconciliation had taken place. ${ }^{58}$ If this was real, no similar happy end could be expected to conclude the hostility initiated by von Born several years later. At the height of the "flood of pamphlets" in 1783, von Born-a one-time Jesuit for just sixteen months who left the order before his novitiate in 1760 , and by this time already the star of the Viennese Enlightenment as the master of Zur wahren Eintracht-published his main work as an anti-clerical satirist. The Specimen monachologiae, methodo Linnaeano, tabulis tribus aeneis illustratum (Specimen of the natural history of the various orders of monks, after the manner of the Linnæan system, also published in German, French, and English) by "Joannes Physiophilus" (von Born's pseudonym) ${ }^{59}$ is cast as an academic

57 Riskin, Science in the Age of Sensibility, 209-25.

$5^{8}$ Mesmer's response was published both separately on January 19, 1775, Sammlung, 31-37, and in the $W D$, no. 6. (January 21, 1775): 9-11. For Hell's rejoinder, dated January 29, 1775, see $W D$, no. 10 (February 4, 1775): 9-11.

59 Scholars usually attribute the work to Born; for doubts, see Josef Haubelt, Studie o Ignaci Bornovi (Prague: Univ. Karlova, 1973), cf. Evans, Austria, Hungary, and the Habsburgs, $46 \mathrm{n} 35$. 
treatise conceived according to the Linnæan method and using the terminology developed by the famous Swedish botanist. Thus, the genus of the monk is in general defined as an "animal" that is "anthropomorphic, hooded, wailing at night, thirsty." Moreover, the body of the monk is "two-footed, erect, with a back that is curved inward, a head that is flattened from above, always hooded and clothed on all sides, except for certain species whose head, feet, ass, and hands are nude." 60 The various monks are then distributed in their species (orders) - such as Monachus Benedictinus, Monachus Dominicanus, Monachus Camaldulensis etc.-and described as though they were specimens of natural history. Jesuits were, strictly speaking, not "monks," and the Society of Jesus had in any case ceased to exist by this time, so it was spared description in von Born's merciless satire. Nevertheless, the first German edition of the work was attributed to an "Ignaz Loyola Kuttenpeitscher" - and sold two thousand copies in a mere three weeks. ${ }^{61}$ It might be added that the publisher of the Latin original is also spuriously given as "P. Aloys Merz." Alois Merz (172792), dean of the cathedral of Augsburg, was another former Jesuit and one of the sharpest Catholic polemicists of the time.

Worse was to come from Hell's point of view, on an ad hominem basis. In 1771, as a central figure of the Prague cultural and scientific scene, in the inaugural issue of the review journal Prager Gelehrte Nachrichten (Prague learned news), von Born still commended Hell, along with Rieger, Kollár, von Jacquin, Stepling, and others, as an outstanding representative of enlightened science in a "domestic" context. ${ }^{62}$ In the same year in the same journal, von Born published a review of Sajnovics's Demonstratio, not calling into question its main propositions, but criticizing the author's - according to von Born, a fellow expert of natural knowledge, not sufficiently stringent-notion of "demonstration" (i.e., proof). As an aside, von Born added that he sustained his judgment on the implications of the treatise for the early history of Sajnovics's countrymen until the publication of the "very promising work of the famous father Hell, already announced under the title Expeditio litteraria ad Polum arcticum" - but worried that "the undertaking of Mr. Sajnovics to make Hungarians the descendants of Lapps" would create some storms. ${ }^{63}$ By a decade later, all the respectful distance was gone. Von Born then published a satire entitled Telescopium Christiano-Hellianum (Christian-Hellian telescope), targeting Hell

6o [Ignaz von Born], Joannis Physiophili Specimen Monachologice methodo Linnceana tabulis tribus ceneis illustratum, cum adnexis thesibus e Pansophia P.P.P. Fast [...] (Augsburg: Merz, 1783), [17].

61 Robertson, "Curiosity," 139.

62 "Vorbericht," Prager Gelehrte Nachrichten 1, no. 1 (1771): 2.

63 Prager Gelehrte Nachrichten 1, no. 13 (1771): 200-6. Cf. Eszter Deák, "Born Ignác ismeretlen recenziója Sajnovics János ‘Demonstratió’-járól,” Hungarológia 2 (1993): 117-21. 
directly. Cast as a call for subscriptions modeled upon Hell's advertisement for the Expeditio litteraria, it bears the false signature of the court astronomer, who is also styled "historian of the Lappish nation, apostolic missionary of the Roman see." ${ }^{64}$ Printed leaflets were circulating in Vienna by the autumn of 1784, and in 1786 the piece was included in von Schlözer's widely disseminated Göttingen journal on public affairs, the Staats-Anzeigen (State reports). One thread in the contents is the mockery of Hell's inability to bring his great work to conclusion: von Born put into the astronomer's mouth an account of how "after sweating over this work for ten years," he decided to "say goodbye to all mundane issues" and to "ascend from astronomical matters even higher into the heavens, and henceforth treat nothing but spiritual and divine subjects."65 In this spurious call for subscriptions, Hell is portrayed as a sworn enemy of the freemasons, with the full title of his work given as The Christian-Hellian Telescope, or Macro- and Microscopic Observations on the Heresy and Goal of the Freemasons by Honorable Father Maximilian Hell of the Society of Jesus' [sic], Made upon His Return and Repentance from Speculations concerning Matters Relating to Venus. ${ }^{6}$ The work was supposed to be brought out by the publisher "of our Society, in three volumes, although not in folio, but, as befits Christian modesty, in octavo."67 Furthermore, the volumes were to appear on the day of Saint Xavier in the year 1784, on the day of Saint Aloysius in the year after, and on the day of Saint Ignatius in 1786. Subscriptions were open "in all Catholic cities and provinces, at the Honorable Father Preachers and ex-Jesuit Missionaries." 68

The reference to Hell as "Honorable Father of the Society of Jesus," the naming of canonized representatives of the same Society (Xavier, Aloysius, and Ignatius Loyola), the supposed existence of a Jesuit press and even of ex-Jesuit missionaries - all was neatly phrased in order to nail the Viennese court astronomer as a spearhead of anti-tolerant schemes against the freemasons. Further attacks on Hell's reputation came in various newspapers and ephemeral publications in the mid-1780s. ${ }^{69}$ To at least one of these-an "anecdote illuminating Austrian ex-Jesuitism, or Jesuitism," alleging Hell to be the local

64 In some of the literature, this signature has been taken at face value and the contents of the call have been discussed as though the text had been written by Hell. See Pinzger, Hell Miksa, 1:25-26.

65 [Ignaz von Born], "Lectori salutem," Staats-Anzeigen 9, nos. 33-36 (1786): 228-31, here 229.

66 [von Born], "Lectori salutem," 230.

67 [von Born], "Lectori salutem."

68 [von Born], "Lectori salutem," 231.

69 According to Steinmayr, "Geschichte der Universitätssternwarte," 271-73, these included the Oesterreichische Biedermanns-Chronik, the Wienerische Kirchenzeitung, the Briefe aus dem Himmel, and the Phantasten- und Prediger-Almanach. 
intermediary in a surviving Jesuit network who supplies brethren with travel money on their way to the remaining bastions in the Russian Empire (in this particular case, a Dutch fellow en route to Mogilev) - Hell wrote an angry retort, and threatened legal steps against the editors in case the "fabrications" were repeated. ${ }^{70}$ Elsewhere, he was even listed as having died-morally speaking - in the year 1773, in the midst of his "struggle for the good cause."71 Freedom of press took its toll on the ex-Jesuit, who complained to Kästner:

You will, renowned gentleman, forgive my long silence if you learn that I am not at all enjoying the kind of peace of mind I did just a few years ago. The Viennese scribblers impugn men of all standing with full freedom, so even I, who have not hurt or harmed anyone, and have never written anything apart from astronomical matters, cannot be tranquil [...]. I cannot even sleep, and I am forced to refute the slander and the lies of those who want to ruin my reputation $[\ldots] .{ }^{72}$

A visitor to Vienna in the autumn of 1784 , the German-speaking Danish citizen Friedrich Münter (1761-1830) has left a detailed diary that can be compared with the testimony of Hviid from six years earlier. Like Hviid, Münter was on a study trip, transcribing old manuscripts and visiting libraries and archives. Unlike Hviid, however, Münter was a freemason, and on the very day of his arrival in Vienna, he visited von Born. In fact, during his seven weeks in the Austrian capital (from August 30 to October 20, 1784), Münter paid visits to the von Born family virtually every day. He also went to see the papal nuncio, Garampi, whom he appears to have sympathized with, despite the denominational distance. It was through Garampi that Münter was introduced to Hell, "a thin, deteriorated little man, in whom the sly Jesuit is at the same time before one's eyes."73 Münter met Hell on only three occasions, but heard from various sources enough sensational rumors about this famous ex-Jesuit to fill several pages of his diary.

70 "Anekdote zur Beleuchtung des österreichisches ex-Jesuitismus, oder Jesuitismus," Wienerische Kirchenzeitung, no. 34 (August 23, 1786): 549-50; "Erinnerung an das Publikum," Wiener Zeitung, no. 75 (September 20, 1786): 2246.

71 Steinmayr, "Geschichte der Universitätssternwarte," 272.

72 Hell to Kästner in Göttingen, March 6, 1785. NSUBG; Hungarian translation in Csaba, Hell Miksa írásaiból, $57-58$.

73 Frederik (Friedrich) Münter, Frederik Münter: Et mindeskrift II; Aus den Tagebüchern Friedrich Münters; Wander- und Lehrjahre eines Dänischen Gelehrten, vol. 1, 1772-85, ed. Øjvind Andersen (Copenhagen: P. Haase \& Son, 1937), 62 (entry on September 7, 1784). 
According to Münter, the Society of Jesus was never really suppressed. It still prospered not only in Russia but even in the Austrian lands, where there were supposed to exist four large prelatures-in Innsbruck, Lviv, Vienna, and a fourth, unnamed place. The Jesuits were said to hold secret nocturnal meetings in Vienna, over which Hell presided as the superior (Grosmeister) ${ }^{74}$ Moreover, the court astronomer allegedly cultivated close contacts with the Jesuit order in Russia and profited from support by a network of Jesuit-friendly bishops like the one of Eger in Hungary. Throughout, Münter characterizes Hell as an extremely dishonest man, who complained about "these times of unbelief" (unglaubigen Zeiten) and saw little value in the freedom of the press, which he preferred to call "recklessness" (Zügellosigkeit). ${ }^{75}$ In sum, Hell was one of those

elected munitions of God, fighting to prevent the creed of the Jesuits from becoming extinct, and he really devotes himself with all his might in this struggle. A substantial part of the pamphlets directed against the emperor passes through his hands. He either writes them himself, or orders others to write them, and thereafter passes them on to his beastly horned [i.e., Satanic] colleague, who immediately submits them to be printed in the press of the order. ${ }^{76}$

It is difficult to judge the exact level of exaggeration in the rumors to which Münter's diary apparently gives full credit. In some of the literature, it is reported-unfortunately, without references - that in the 178 os Hell recruited a team of Catholic polemicists and coordinated their literary efforts to fight the torrent of freethinking unleashed in the tolerant atmosphere of Josephism. ${ }^{77}$ $\mathrm{He}$ is also said to have personally discussed the spirit of anti-clericalism arising under Joseph II with Pius VI during the pope's visit to Vienna in the spring of 1782, and to have collaborated with Merz in editing and publishing a series of works in Catholic apologetics in Augsburg. All these works, however, are alleged to have been lost. ${ }^{78}$ Elsewhere, it is claimed that he supported the

\footnotetext{
74 Münter, Frederik Münter, 83-85 (entries on September 26 and 27, 1784), here 85 .

75 Münter, Frederik Münter, 77 (entry on September 23, 1784).

76 Münter, Frederik Münter, 65-66 (entry on September 11, 1784).

77 Hell had a problem with toleration only when it concerned other denominations, but applauded the policies of Frederick II of Prussia, expressing joy over the protection extended to the Jesuits in Silesia. Hell to Bernoulli in Berlin, dated Vienna, March 1, 1775 (Uвв).

78 Kisbán, Hell Miksa, 18. The monographer of Merz does not seem to be aware of any meaningful cooperation between him and Hell. Cf. Fred Horstmann, Alois Merz, Dom- und Kontroversprediger aus Augsburg, als Opponent der Aufklärung (Frankfurt: Peter Lang, 1996).
} 
unfolding popular piety focused on the adoration of the heart of Christ (Cordis Jesu), supporting it with the distribution of leaflets and other material, for which he was even inflicted a fine of five hundred florins. ${ }^{79}$ In lack of conclusive evidence, we may presume that as a devout Catholic and devoted ex-Jesuit, Hell did everything he soberly could to resist the tide and preserve his own and his fellow believers' integrity, but also that he was limited in his ability to do so owing to his position as a state servant and his commitment to his vocation. He could hardly have afforded the risk of operating as the hub of a network of plotters. ${ }^{80}$ At the same time, Hell had other means, more anchored in his professional life, of holding his own in the face of the adversity newly surrounding him in the metropolis: a resort to the credit he had accumulated in the supraimperial space of the Republic of Letters, and his connections in the subimperial space of the eastern Habsburg provinces.

It has been mentioned that after the suppression of the Society of Jesus, some former Jesuits continued their career abroad, and Hell as an internationally acclaimed man of science may have had better than ordinary opportunities to do so. In an editorial comment on von Born's mockery of Hell's failure to complete the Expeditio litteraria, von Schlözer added: "Mr. Hell was nevertheless elected a fellow of the Royal Society of Sciences in London in the preceding year." 81 Similar and even greater claims are made in some of the historiography, about Hell receiving offers of "honorary pensions much higher than his salary" from both Christian VII of Denmark and George III (1738-1820, r.1760-1820) of Britain, ${ }^{82}$ or a "call to England with a considerable salary [...] at the time of the suppression of the Society." ${ }^{83}$ Hell is said to have declined these offers, and in lack of source reference, it is hard to establish the facts about them. In any case, Hell's name is missing in the official lists of fellows of the Royal Society of London. The only Jesuits who were elected fellows during the eighteenth century appear to have been Boscovich, Christian Mayer, and Marcin Poczobut

\footnotetext{
79 Pinzger, Hell Miksa, 1:27.

8o Münter's account recalls the topoi of the near-hysterical injunctions of several figures of the contemporary German public scene to avert a conspiratorial offensive of the Catholic Church against Protestantism and the Enlightenment. Cf. Johannes Rogalla von Bieberstein, Die These von Verschwörung 1776-1945 (Frankfurt: Peter Lang, 1976), 5-32.

81 [von Born], "Lectori salutem," 229.

82 Ferrari d'Occhieppo in Gillispie, Encyclopedia, 6:234.

83 Schreiber, "Jesuit Astronomy (Part II)," 111.
} 
(1728-1810), the head of the observatory in Vilnius. ${ }^{84}$ Moreover, Hell appears to have had no personal contact in erudite circles in England until 1776, when he finally received an answer from the astronomer royal, Maskelyne, upon repeated requests for help in furnishing the Eger observatory with instruments. ${ }^{85}$

The hint of a Danish offer has a more solid foundation in the sources. In a request submitted to the imperial and royal chamber in July 1781, Hell asked for a higher salary, which he justified as follows:

Because I, in consideration of the honor of the imperial and royal court, rejected an offer of a yearly personal pension of a thousand Gülden as a token of gratitude for my highly strenuous and dangerous journey to the island Vardøhus in the Arctic Ocean, where I observed the transit of Venus in front of the Sun. I refused to receive this pension because I, as imperial and royal court astronomer, deemed that it would be negative for the honor of the imperial and royal court if I benefited from a pension of a foreign court in conducting my work. ${ }^{86}$

There is no mention of any similar offer from England either in this letter or in any other source available for this study. Hell never seems to have seriously contemplated abandoning his position in Vienna, and if he wanted to improve his situation, he used the instruments still in his hands after the dissolution of his order. One of these instruments was the Ephemerides. The annual had become an indispensable source of up-to-date astronomical knowledge by virtue of the continent-wide and partially global collection, publication, and interpretation of data. If anything, it could have been a means for Hell to retain or expand his scope of maneuver internationally when it had become narrowed locally.

The profile of the Ephemerides underwent some change after 1769, when as a consequence of Hell's departure for the Arctic expedition the editing of the annual was taken over by one of his assistants, Pilgram, who did not publish observation reports until 1771, and relatively few ones both in that year and in $1772 .{ }^{87}$ By compensation, the 1771 volume included Hell's account of his 1769 transit observation, and the following one a collection of all the observations

84 Udías, Searching the Heavens and the Earth, 5, supplemented by Moutchnik, Forschung und Lehre, 349-52.

85 Cf. above, $170 n 108$.

86 Hell to the Kaiserl: Königl: Hofkammer in Vienna, n.d., but according to an administrative note received July 25, 1781 (Akademie der Wissenschaften in Vienna).

87 An earlier version of the argument of the following paragraphs was presented in Kontler, "Uses of Knowledge." 
around the world, followed by Hell's treatise on the parallax. The trend continued for the following two years as well. Instead of observation reports, in 1774 we still find supplements to Hell's dissertation on the solar parallax (Lexell's long letter from St. Petersburg, and a shorter treatise by Pilgram on the subject), ${ }^{88}$ and in 1775 , two treatises by Hell (an article on the diameter of the moon alongside the method of calculation of latitudes). ${ }^{89}$

Reports on astronomical observations appear again in a respectable number in the Ephemerides from 1776 onward, but the coverage is conspicuously different from pre-1768 times. It embraces in an apparently haphazard manner a few locations from Central Europe, broadly speaking (besides Vienna, only Kremsmünster, Ingolstadt, and Greifswald), from Copenhagen, and exotic places: Beijing (observations by the Jesuit fathers Augustin von Hallerstein, José da Espinha [1722-88], and José Bernardo de Almeida [1728-1805] $)^{90}$ and "Western Tartary" (Felix da Rocha [1713-81]). The year 1777 was especially remarkable in the "regional turn" of the Ephemerides (that is, the shifting geographic distribution of source locations). In that year, as mentioned, the only university operating in the Kingdom of Hungary was moved from Trnava to Buda, where an astronomical tower was created too, similarly to the town of Eger, where a new observatory was being mounted in the local lyceum. Hell was assigned to supervise and advise the building and equipment of both of these new observatories. In 1776-as reported in great detail in the Ephemerides for 1777-Hell completed an astronomical journey in Hungary. From this time on, the yield of observation activity in the metropolitan centers of European science-in France, in England, in Italy (let us remember the comment on the Berlin Jahrbuch in the Journal des Sçavans) are, by and large, missing from the Ephemerides. The space beyond the astronomical tables is quite consistently and overwhelmingly filled, apart from the sporadic appearance of Paris, Milan, and Greenwich in the observation reports, with accounts from the northern, eastern, and central crescent around the European core, as well as contributions of Hell's colleagues (especially Pilgram), and Hell himself.

88 The texts by Hell and Lexell were mentioned and discussed above. The additional item is "De parallaxi Solis ex duobus internis contactibus Veneris, in eodem loco observatis disquisitio. à P. Antonio Pilgram S.J. anno 1772" (140-55). There is also an "Appendicula à P. Hell, itemque solution ultimissimi problematis à R.P. Hallerstein Pekini Sinarum Mandarino" (155-62).

89 "Methodus accurata, ope solius tubi micrometrum instructi, praecisam definire elevationem poli"; "Dissertatio, de vera magnitudine apparente diametri Lunae plenae oculo inermi visae," Ephemerides 1775 (1774), 3-41; 42-53.

9o Hell also mentions in their company a certain "Cibolla," whom we have been unable to identify. 
Besides this geographic reorientation, there was still an attempt made at coherently organizing the material collected during the Arctic expedition, as already discussed in Chapter 5 . As regards the observation data, one conspicuous development is the proliferation of material from Scandinavia: besides Copenhagen, we find Lund, Roskilde, Trondheim, Iceland, and Greenland as new source locations. In addition, astronomical activity in Germany and the Habsburg monarchy was vigorously promoted in the appendices of the Ephemerides during the last fifteen years of Hell's life. Besides some German venues, striking presences are-naturally—Vienna, besides Prague and Kremsmünster. Above all, however, Hell was careful to emphasize the achievements of Trnava, Buda, and Eger.

To a considerable extent, the explanation of these shifts of emphasis is quite evident: while some links of the Jesuit chain became broken and Hell had to cook with what he had been left, the new Scandinavian contacts partially made up for the loss. What deserves attention is the surge in the representation of astronomical activity in Hungary, not only and necessarily in the volume of reporting but its hyper-enthusiastic tone. Being confronted with new realities and pressures in the imperial center-still a high-level state servant, but deprived of the institutional (and spiritual) leverage of his order, with certain avenues of government patronage blocked before him, and unprotected against attacks in the arising local public sphere-Hell appealed to the corners of the realm he had learned to love and appreciate during his highly mobile early career, and began extolling their virtues internationally through the Ephemerides.

The astronomical journey of 1776 was in a sense a revisiting of these roots in the northern and eastern parts of the Hungarian half of the Habsburg monarchy, combined with the pleasing awareness-amply expressed in the report published in the Ephemerides - that the creation of new observatory towers there, together with the already existing ones, might elevate the status of these parts as a power to reckon with in the discipline. On this journey, Hell had a companion: Madarassy, sent in 1774 to study with him in Vienna by Bishop Eszterházy, who had been in contact with Hell for a decade by then.${ }^{91}$ In Eszterházy, perhaps the most erudite churchman of eighteenth-century Hungary while a stout opponent of the Viennese reforms, ${ }^{92}$ the court astronomer must

91 See above, 130 and 353 .

92 For the bigger picture on the position of Hungarian bishops vis-à-vis Viennese policies throughout the eighteenth century, see Joachim Bahlcke, Ungarischer Episkopat und österreichische Monarchie: Von einer Partnerschaft zur Konfrontation (1686-1790) (Stuttgart: Franz Steiner Verlag, 2005). 
have recognized a potential champion of Catholic learning who might restore it to its former glory after the suppression of his order.

Hell's detailed report in the Ephemerides about the five-week journey he took with Madarassy from Vienna to Eger and back is a remarkable document. Besides recording the data of observations carried out at each station-aimed chiefly at a more accurate determination of the geographic latitude of several locations in Hungary, thus correcting the "grave errors" contained in Ignaz Müller's Mappa geographica novissima regni Hungariae (The most recent geographic map of the Kingdom of Hungary [1769] ${ }^{93}$ — the account provides a wealth of interesting insights into the cultural environment in which the journey took place. Praises lavished by Hell on the benevolent bishop of Eger, characterized as a munificent patron of learning, are a recurrent theme. Eger is portrayed as a virtual "center of advanced science," and the bishop himself as a devout Christian purportedly with a Jesuitic frame of mind. Looking on as Hell and the rest of his team draws the meridian line of his observatory, Eszterházy is said to be contemplating

no doubt, in his pious mind those words of David, the Heavens will tell of the glory of God, and the firmament announce the works of his hands as well as that holy dictum of Divine Ignatius Loyola, who having observed the stars at night said, O how dirty the Earth appears, as I look at the sky. ${ }^{94}$

Even apart from the bishop, the territory is quite densely populated with further men of eminent learning. They include not only old friends and associates, such as Weiss in Trnava and Sajnovics, now professor of mathematics at the university recently moved to Buda, the "metropolis of Hungary." Mention is made of Balajthi, Eszterházy's first protégé to have studied with Hell at the Universitätssternwarte in 1762 (now vicar at the nearby market town of Kunszentmárton), and the former archivist of the episcopal collections, Mátyás Kotuts (dates unknown), who had just succeeded Balajthi as professor of mathematics at the gymnasium of Eger. Further, we meet the illustrious prior of Eger (formerly the erudite librarian of the Collegium Germanicum et Hungaricum in Rome, and later bishop of Alba Iulia [Gyulafehérvár, Weissenburg] in Transylvania), Count Ignác Batthyány (1741-98), and on the backward

93 An army officer, Müller (c.1727-1804) was only a namesake of Maria Theresa's abovementioned Jansenist confessor. The map project was supervised by the president of the Viennese military court council (Hofkriegsrat), the famous general count Franz Moritz Lacy (1725-1801), the future initiator of the land survey of Joseph II.

94 Maximilian Hell, "Observationes astronomicae latitudinum geographicarum sive elevationum poli, lep, factae 1776," Ephemerides 1777 (1776): 273-89, here 279-80. 
journey the prior of the cathedral of Veszprém, Pál Kiss. In this country swarming with men of superior learning (invariably good Catholics, several of them directly emerging from a Jesuit background), even the common man is distinguished by a keen "interest in mathematics" - as in the case of the innkeeper of the village of Szered, for example: this Hungarian counterpart of the Tyrolean farmer Anich, whose mathematical prowess had been used as a proof for the excellence of Catholic education by Hell a decade earlier, was watching in admiration Hell drawing a meridian line with a stick on the floor of his house. ${ }^{95}$ At the end of the account, Hell, as it were, sighs in relief: "Thus my tour of Hungary for the improvement of astronomy and geography $[\ldots]$ and for the greater glory of God is completed." 96 That the latter phrase was also the motto of the temporarily defunct Society of Jesus is noteworthy. Decision-makers in the imperial center may have turned hostile to the tradition of science represented by Hell and his attempts to find new institutional bulwarks for it by sponsoring an academy of sciences. But these traditions seemed-or at least were represented by him - to flourish in the province of the realm that he called his "fatherland" (Patria mea), ${ }^{97}$ with a powerful and generous patron, and a substantial rank-and-file of dedicated scholars. Finally, thereis theissue of cross-disciplinary engagement and appropriation. Hell informs his readers about an excursion that he has made, at the request of von Jacquin, to the town of Jászapáti ${ }^{98}$ to verify rumors of a special, edible plant. The edible plant did indeed exist; he brought some specimens back to Vienna for further scrutiny by the head of the botanical garden. In a self-assured aside filling more than two pages, he adds that he had known about the plant since his stay in Transylvania, where it proliferated to such an extent that he presumed it to be well known to botanists. Furthermore, he also took the opportunity to gather several other exotic specimens as a service to von Jacquin, thereby placing himself on a par with the famous explorer with respect to the natural kingdom, at least in regard of endemic Hungarian plants. ${ }^{99}$

95 Hell, "Observationes astronomicae latitudinum geographicarum," 167 (flawed pagination: correctly 276). It may be worth noting that the village was located on the estates of the bishop's brother, Count Ferenc Eszterházy (1715-85), head of the Hungarian Court Chancery, another important patron of culture and an enlightened improver of his estatesand an opponent of Josephian centralization. Hell stresses that the "elegantly constructed" inn itself was also built thanks to his support.

96 Hell, "Observationes astronomicae latitudinum geographicarum," 289.

97 Hell, "Observationes astronomicae latitudinum geographicarum," 278.

98 Or "Jasz-Apáthy," as Hell spells it; in contrast to practices earlier established for the Ephemerides, the Hungarian name form is highlighted, with the Latin explanation "the town of Jaszigia near the river Tybiscus [Tisza]" added in smaller characters.

Hell, "Observationes astronomicae latitudinum geographicarum," 282-84. 
Over the subsequent years, we find Hell making efforts to support these provincial initiatives with all the weight of his scientific expertise and the institutional means still available to him. His correspondence is replete with detailed advice and instructions to Weiss concerning the construction of the university observatory in Buda. ${ }^{100}$ The 1780 and 1781 volumes of the Ephemerides gave generous space to reporting about the astronomical activity carried out at the new observatories of the Kingdom of Hungary, the "most splendid new observatory of Eger" being especially commended. ${ }^{101}$ Thus, the reputation of the Ephemerides, once established in cosmopolitan contexts and by cosmopolitan means, was put into the service of a patriotic project of promoting scientific knowledge produced in local, Hungarus spaces.

In his correspondence, Hell was quite explicit that this was in direct defiance of unpleasant developments in the metropolitan center. In the letter to Bernoulli already cited, complaining about the increasing narrow-mindedness of the Viennese government in supporting the sciences, he came to the conclusion that "my Hungary (for I am myself an Ungarus) has a more sound attitude to astronomy, which is held in high esteem among the Ungari," adding as a demonstration data from the recently published compendium of statistician Ignaz de Luca (1746-99) on "Austrian" men of learning, Das gelehrte Österreich (Learned Austria, 2 vols. [1776, 1778]): "Among these prominent authors, Ungari make up the largest proportion [...]; this demonstrates that Hungary has flourished, and still flourishes, more than the rest of the hereditary kingdoms with respect to the cultivation of all manner of sciences."102 Hell may have been disturbed by the fact that de Luca categorized him as an "Austrian" on the grounds that his parents were "both born Germans,"103 and perhaps consoled

100 Hell to Weiss on February 16, 1779; on April 14, 1779 (twice); on June 9, 1780. In Pinzger, Hell Miksa, 2:128-34.

101 Maximilian Hell, "Observationes astronomicae Agriae in Ungaria in observatorio novo Excellentissimi, Illustrissimi ac Reverendissimi Episcopi Agriensis D.D. Caroli, e Comitibus Eszterhazi," Ephemerides 1780 (1779): 32-33; Hell, "Observationes astronomicae in Novo Observatorio Universitatis Regiae Buda in Ungaria, a Cel. D. Francisco Weiss Astronomo Regio Universitatis," Ephemerides 1781 (1780): 28-29. During the last decade of Hell's life, whenever observation reports were published in the Ephemerides at all, Buda was included, though Eger less regularly. In this period, the reporting activity was fully confined to the main observatories in the Habsburg monarchy (besides the ones in Hungary, Vienna, Kremsmünster, Prague), with sporadic attention to Scandinavian sites.

102 In the same letter, Hell elaborated in considerable detail on the merits of the bishop of Eger in supporting the cultivation of the sciences, astronomy in particular, in Hungary, as well as the spectacular development of the observatories of Trnava and Buda. Hell to Bernoulli in Berlin, February 15, 1777 (Uвв).

103 Ignaz de Luca, Das gelehrte Österreich: Ein Versuch (Vienna: Von Ghelen, 1776-78), 1:176. 
by his inclusion in a bio-bibliographical encyclopedia of "Hungari and people from the provinces that have made themselves known through published writings," published in the same year as de Luca's first volume. ${ }^{104}$ In any case, with the help of the Ephemerides, Hell was offering a map of "learned Austria" that recorded the changes explained to his esteemed colleague, another influential voice in the respublica astronomica: a shift of the center of gravity to the east.

This representation of the situation was, of course, much too sanguine. ${ }^{105}$ While the observatory of Eger indeed performed well, with Madarassy as its astronomer after he had finished his training with Hell in 1778, a full-scale infrastructure of higher learning that a university would have been, proved to be wishful thinking. The medical academy in Eger, opened in 1769, was forced to close in 1775 because of the royal withdrawal of the right of the institution to confer doctoral degrees. By the time the construction of the would-be university building was completed in 1785 , clause 14 of the Ratio educationis or general law of education for the Kingdom of Hungary (1777) had stipulated that there was to be a single university in the whole of the kingdom: "The one splendidly located in the very midst of the country [in Buda], endowed with rich funds and teaching personnel well trained in all manner of sciences." ${ }^{106} \mathrm{~A}$ second layer of tertiary education was also created, with five academiae or Hochschulen, in Győr, Oradea (Nagyvárad, Grosswardein), Košice (losing its university status), Zagreb, and Trnava. The school at Eger remained a lycée, not even allowed (as Eszterházy requested in 1784) to be a temporary host to the university evacuated from Trnava but not yet possible to accommodate conveniently in the capital of the Hungarian province.

Hell nevertheless remained in close contact with Bishop Eszterházy. Besides matters of science, after the debacle of the university plans the religious and ecclesiastical issues of the day acquired greater prominence in their correspondence. One subject that Hell discussed in two letters in quick succession in 1779 was the forced retraction of the tenets put forward in the famous 1763 treatise De statu ecclesiae (On the state of the church; better known as Febronius, promoting a return to the conciliar tradition of government in the Catholic Church) by its author, Johann Nikolaus von Hontheim (1701-91), auxiliary

\footnotetext{
104 Elek Horányi, Memoria Hungarorum et provincialium scriptis editis notorum (Vienna: Loew, 1776), 2:81-90.

105 There is no scope here to examine either Hell's judgment of the policies of Vienna with those it actually pursued in the matter, nor the amount of wishful thinking at the bottom of the proposed "shift."

106 Aladár Friml, trans. and ed., Az 1777-iki Ratio educationis (Budapest: Katholikus Középiskolai Tanáregyesület, 1913), 50.
} 
bishop of Trier. ${ }^{107}$ Hell noted the prominent role of nuncio Garampi in achieving this "real triumph of the Catholic Church," but reported to Eszterházy with disappointment that it is not well received by the "perverted Catholics of this city of ours."108 Further fulminations concern the "insults" to the Catholic Church constituted by designs to alleviate regulations on fasting and even to abandon priestly celibacy ("after a Lutheran manner"). ${ }^{109}$ Nevertheless, Hell continued to tackle in his letters scholarly developments as well, never losing the hope that the Eger school, this "most splendid palace of the muses,"110 might eventually provide a "safe and permanent haven" for the university of Hungary. ${ }^{111}$ The latter expectation was made explicit by Hell after the accession of Leopold II early in the year 1790. The seventy-year-old ex-Jesuit at that time became involved in a new edition of the Statutes of the University of Vienna, and made efforts to convince the policy-makers of the need for a purely Catholic university system. ${ }^{112}$ As he explained to Eszterházy, he hoped to

restore the studies at the universities of our hereditary realms, which now lie with their backs broken, to their ancient status and spirit in the same manner as the university studies were restored during the reign of the pious emperor Ferdinand II, at first in Vienna in the year 1623, and thereafter in all the cities of the Austrian hereditary realms. ${ }^{113}$

These hopes were to be frustrated again. Hell's scientific output became also somewhat scaled down during the 1780 s. Though even in the very last years of his life, he published two fragments of the Expeditio litteraria in the volumes of the Ephemerides for 1791 and 1793, the major astronomical contributions to the supplements of the annual in the 1780 s were either authored by Hell's serving

107 For a comprehensive overview in English, see Ulrich Lehner, "Johann Nikolaus von Hontheim's Febronius: A Censored Bishop and His Ecclesiology," Church History and Religious Culture 88, no. 2 (2008): 205-33.

108 Hell to Eszterházy in Eger, dated March 19, 1779. FLE AV 2629. The discussion continues in the letter of April 9, 1779, FLE AV 2629. As for the "perverted Catholics" of Vienna, supporters of Josephist ecclesiastical policies indeed regarded the retraction as one of the most dangerous writings "against worldly regents." Cf. Lehner, "Hontheim's Febronius," 226.

109 Hell to Eszterházy in Eger, dated October 15, 1779. FLE AV 2629.

110 Hell to Eszterházy in Eger, dated December 26, 1783. FLE AV 2629.

111 Hell to Eszterházy in Eger, dated October 30, 1790. FLE AV 2629.

112 In an extant copy of the 1791 edition of the Statutes, an autograph letter by Hell was pasted between pages 167 and 168, revealing "his contempt for Protestant education, calling Protestant universities 'pseudo-Universities' that 'corrupt students' minds."' See Shore, Jesuits and the Politics of Religious Pluralism, 105.

113 Hell to Eszterházy in Eger, dated November 1, 1791. FLE AV 2629. 
assistant von Triesnecker or by his former assistant Pilgram. ${ }^{114}$ However, the volumes for 1788 and 1789 contain a number of pieces that attest to his ability, in his advanced years, to adopt a perspective on major issues in his profession, and to highlight these in a genre that was very different from all of his previous contributions; and he did so in a way that harmonized with the strategy of emphasizing his Jesuit and Hungarus allegiances.

In 1781, Frederick William (Friedrich Wilhelm) Herschel (1738-1822) ascertained that a celestial body he had observed was not a star, but a planet, which at first he named Georgian star (after King George III), but it became universally known as Uranus. This first discovery of a planet in the solar system since antiquity became a sensation, in spite - or precisely because — of the fact that the existence of such a planet had been predicted on purely speculative grounds as an inevitable part of a structurally consistent cosmology by Kant in his Allgemeine Naturgeschichte und Theorie des Himmels (Universal natural history and theory of the heavens [1755]). In turn, Kantian speculative cosmology was not dissimilar in its narrative scope and ambition to biblical cosmogony and mythical astrology, which also received significant stimuli from the "new science" of the seventeenth and eighteenth centuries. Together, they have been shown to have supplied a great deal of inspiration for astronomical didactic poetry, a genre that flourished in eighteenth-century Hungary. ${ }^{115}$ It was such a piece of poetry, the Historia Uraniae musae (History of the muse Urania) by György Alajos Szerdahely (1740-1808), originally published in the previous year, that introduced the appendix of the Ephemerides for 1788. This was followed by another poem, by Hell himself, the Lis astronomorum (The feud of astronomers-i.e., the controversy on the naming of the new planet). Szerdahely soon composed a companion, Elegia epidictica, per quam demonstratur Uraniam musam esse primogenitam Urani (Epideictic elegy demonstrating that the muse Urania was Uranus's first born) and republished along with the Historia and the rest of his collected poetical works in 1788 in a volume entitled Silva Parnassi Pannonii (Forest of the Pannonian Parnassus).

114 Cf. Sommervogel, "Hell, Maximilien," 244-46. Beginning in the late 1780s, the highly talented, but far less renowned astronomer Johann Tobias Bürg (1766-1834) also took part in observations at the Vienna University Observatory. After Hell's death in 1792, he served as von Triesnecker's adjunct and co-editor of the Ephemerides. For a popular account of Bürg's career, see Maria G. Firneis, “Johann Tobias Bürg (1766-1834): Littrows Gegenspieler in Wien," Die Sterne 69 (1993): 148-53.

115 Piroska Balogh, "Sic itur ad astra: Változatok a csillagászati tanköltemény műfajára Szerdahely György Alajos és Pálóczi Horváth Ádám műveiből," in Magyar Arión: Tanulmányok Pálóczi Horváth Ádám müveiről, ed. Rumen István Csörsz and Béla Hegedüs (Budapest: Rec.iti, 2011), 101-12, here 104. 
Excerpts of the Elegia were then included by Hell, with lengthy annotations and a celestial map of new constellations named after George III and Herschel, accompanied by their eulogies, in the Ephemerides for $1789 .{ }^{116}$

Szerdahely was appointed in 1774 as the first professor of aesthetics at the University of Trnava (then Buda, and finally Pest) before being transferred to the position of director of the university's gymnasium in 1784 . He was the author of the first comprehensive work on aesthetics in Hungary (Aesthetica $[1778])^{117}$ as well as important studies on general poetics (Ars generalis poetica [1783]) and genre theory (Poesis narrativa and Poesis dramatica [1784]) — and a fellow ex-Jesuit of Hell's. Like Hell, Szerdahely was a strong devotee of the legacy of his order, often lamenting its demise in his poetry, ${ }^{118}$ and also like Hell he suffered denigration from "enlightened" circles. ${ }^{119}$ The significance of the two astronomical poems for Szerdahely himself is highlighted in the preface to the Silva Parnassi Pannoniae, in which their place is pivotal, and which is dedicated to Hell in recognition of his encouragement to Szerdahely to compose and publish such poetry. ${ }^{120}$ "Poetry and astronomy have always been friends, as they have been brothers, too," both of them "dwelling in heaven," where already Plato located the muse of poetry along with her sister Urania. Szerdahely expresses his conviction that Hell, who campaigned to rename the new planet Urania in the debate related in the Lis astronomorum, had a "poetic spirit" himself, thanks to his outstanding inquiries into the "eternal worlds" jointly governed by the two muses and the arts they represent. ${ }^{121}$ The heavens are portrayed as embracing a physical universe of celestial bodies as well as a cosmos of fiction, accessed and interpreted by human creatures with the means of a dual code: the one by astronomy and the other by poetry. Both of these are in need of resorting to a spiritus poeticus, which according to its original Greek

116 The three pieces are found in the Ephemerides 1788 (1787): 273-302 and 305-15; and the Ephemerides 1789 (1788): $33^{2-56 .}$

117 This work earned Szerdahely considerable international recognition. On this, as well as biographical information and a general reassessment of Szerdahely's fairly neglected and under-appreciated contributions, see István Margócsy, "Szerdahely György művészetelmélete," Irodalomtörténeti Közlemények 93, nos. 1-2 (1989): 1-34; and Piroska Balogh, Teória és medialitás: A latinitás a magyarországi tudásáramlásban 1800 körül (Budapest: Argumentum Kiadó, 2015), 13-102.

118 László Szörényi, “A latin költészet helyzete Magyarországon a XIX. században," Irodalomtudományi Közlemények 89, no. 1 (1985): 1-17, here 6.

119 Margócsy, "Szerdahely művészetelmélete," 5-6.

120 The dedication and the two men's relationship did not escape the attention of the reviewer of the volume for the Allgemeine Literaturzeitung, no. 257 (August 21, 1789): 508-9.

121 Cited in Balogh, "Sic itur ad astra," 106. 
etymology should be understood not merely as "poetic," but also as "creative." Thus, the narrative offered in the Historia of a heavenly coup-at first, the consent of Uranus to her daughter Urania's occupation of a position on the firmament, then her expulsion by the revolt of Saturn, and finally her liberation and restoration thanks to Herschel's discovery-has a "mytho-poetic" character: Urania secures a place for the symbolism of astronomy in poetry, as well as one for poetry in the universe of astronomers. ${ }^{122}$ While this narrative serves to sketch a peculiar cosmology, in the Elegia this cosmology is shown to have an anthropological base: its claim that Adam, the first and prototypical man, was at the same time "the first astronomer," is the metaphorical formulation of the universal human endeavor of observing and understanding the surrounding cosmos, and thereby achieving ascension and immortality. ${ }^{123}$

While Hell must have been flattered by Szerdahely's appreciation and dedication, his own goals in publishing the Buda professor's poems may have been more down-to-earth. On the one hand, he must have conceived them as striking instruments of canvassing his proposition of the name Urania for the new planet (arguing that Uranus is the progenitor of the heavens, not a part of them). In introducing the Lis astronomorum, he styled himself "Uranophilus Austriacus." When sending the Ephemerides for 1788 to Kästner, Hell mentioned that he had sent Bernoulli in Berlin "several copies of the Historia Uraniae, and he replied that the academy was pleased to receive them," and exclaimed: "What will the renowned Mr. Bode do in his Ephemerides with his Uranus?"124 Hell was eager to learn Kästner's opinion on the name Urania, adding:

The name Uranophilus covers Hell, who took up his lute, abandoned in the most hidden cave of Parnassus since he was forty years old, and sang the Apotheosis of the Muse Urania, whose name is hardly known by the poets of our time. In the Historia Uraniae, which we composed with Mr. Szerdahely, all the ideas are mine, and I have supplied more or less all the notes to it. ${ }^{125}$

While in the sources available for this study no ventures into poetry by the court astronomer around or before 1760 could be identified, his attempt to

\footnotetext{
122 Balogh, "Sic itur ad astra," 109.

123 Balogh, "Sic itur ad astra," 210.

124 Hell to Kästner in Göttingen, January 26, 1788 (NSUBG; Hungarian translation in Csaba, Hell Miksa írásaiból, 59). Bode was the first to suggest the name Uranus for the planet.

125 Hell to Kästner in Göttingen, January 26, 1788 (NSUBG; Hungarian translation in Csaba, Hell Miksa írásaiból, 59).
} 
appropriate the work of a collaborator as entirely his own quite closely resembles Hell's redefinition of his role in authoring the Demonstratio nearly two decades earlier. The point is not so much the extent to which this was disingenuous - although, had it not been confined to private correspondence, Szerdahely would surely have resented it: after all, the Buda professor himself was quite knowledgeable about astronomy, also shown by his commemoration of Weiss written upon the latter's death in $1785 .{ }^{126}$ Rather, Hell's effort to appropriate the poem is noteworthy because it shows his deep identification with the approach to the wider significance of an astronomical discovery adopted in it.

Finally, there is yet another perspective on the publication of Szerdahely's poems in the Ephemerides. Like Hell, he was not only a former Jesuit but also a devoted adherent of the Hungarus tradition. He wrote Latin poetry and an Apologia pro lingua Latina (Defence of the Latin language [1790]) as a token of his allegiance to the old cultural markers of the country, and at the diets of both 1790 (as a member of the educational committee) and 1807 he spoke out forcefully for the retention of Latin as the official language of Hungary in church and state. This earned Szerdahely violent detractions among the promoters of Hungarian, despite many unquestionable testimonies of his strong attachment to the literature and culture of his patria, including the appreciation of the beauties of the Hungarian language. ${ }^{127}$ Also like Hell, he was an outstanding scholar, with an increasing international reputation. Especially in conjunction with Hell's correspondence campaign—if Kästner, Bernoulli, and via the latter the Berlin academicians received copies of the Historia, quite certainly others in his broad network were not neglected either-the Ephemerides was once again, as in the case of the 1776 astronomical journey and the activities of the Eger observatory, a vehicle for the international propagation of Catholic cultural and scientific achievement in the Hungarian half of the Habsburg monarchy.

What were Hell's chances of being taken seriously as a Hungarian patriot?128 After all, he had also made his name known as an eager, though not formally

126 György Alajos Szerdahely, Memoria admodum reverendi et Clarissimi Domini Francisci Weiss astronomi celeberrimi (Buda: Landerer, 1785).

127 Margócsy, “Szerdahely művészetelmélete," 8. For Szerdahely's 1807 statement on Hungarian, see Sándor Domanovszky, ed., József nádor iratai, 3 vols. (Budapest: Magyar Történelmi Társulat, 1925-35), 3:74. It must also be added that at the same time he appears to have promoted the spread of Hungarian in education. Cf. Az Ország-Gyúlésének írásai, Acta Comitiorum (1807): 270.

128 For a concise version of the argument presented in the following paragraphs, see László Kontler, "Politicians, Patriots, and Plotters: Unlikely Debates Occasioned by Maximilian Hell's Venus Transit Expedition of 1769," in Sterken and Aspaas, Meeting Venus, 83-93. 
qualified student of themes in Hungarian history and language, emerging as crucial to contemporary discourses of identity. During his lifetime, "language became ideology" in the Kingdom of Hungary — or at least firmly on its track toward achieving such a status ${ }^{129}$ —and the historical study of language was generally consolidating its authority as an indispensable branch of the "sciences of man," whose emergence itself was central to the reorientation of the map of knowledge in the eighteenth century. From this point of view, he may be perceived as responding to developments in the sciences and in the public domain with special sensitivity, but in lack of explicit evidence, one could only speculate as to the extent to which he saw these changes happening. If he did, he may also have realized that there could be political benefits for him in going along. In the post-1773 status quo, when changing circumstances favored the amplification of Hell's Hungarus commitments, his studies devoted to central issues of the genesis of the Hungarian "patria" could have served to consolidate his credentials as a "patriot," and smoothly dovetailed with his efforts to promote the progress of science in the realm.

This would seem like a highly ingenious and potentially promising combination of flexibility in intellectual endeavors (based on open-mindedness and curiosity), and adaptability in social brokerage. Still, in the end Hell was fighting an uphill battle. It is true that in strictly academic circles the theory advanced in the Demonstratio was almost invariably welcomed in Hungary too. As we saw, even Pray felt compelled to modify his earlier views on the subject. It must also be added that the only linguist to champion the alternative concept in Sajnovics's and Hell's lifetime, the eccentric itinerant scholar György Kalmár (1726-c.1782), published his relevant work nearly simultaneously with the Demonstratio, so it could not have been a response to it. ${ }^{130}$ In other words, the issue here was not (yet) that of an academic debate, ${ }^{131}$ the more so as contemporary scholars used the terms "linguistic family" or "linguistic kinship," if

129 István Margócsy, "When Language Became Ideology: Hungary and the Eighteenth Century," in Almási and Šubarić, Latin at the Crossroads, 25-34.

130 György Kalmár, Prodromus idiomatis Schytico-Mogorico-Chuno-(seu Hunno-) Avarici, sive adparatus criticus ad linguam Hungaricam (Bratislava, 1770). Cf. Zoltán Éder, "Újabb szempontok a Demonstratio hazai fogadtatásának kérdéséhez," in Éder, Túl a Duna-tájon: Fejezetek a magyar müvelödéstörténet európai kapcsolatai köréből (Budapest: Mundus, 1999), 47-61, here 49 .

131 This somewhat revisionist view of Hungarian scholarship on the subject is summarized, with references to the now extensive literature, in Réka Lőrinczi, "Megjegyzések és adalékok a finnugor nyelvrokonítás fogadtatásához," Nyelvtudományi Közélemények 97 (2000): 261-72. During the subsequent century, however, a veritable "Ugrian-Turkic war" gradually unfolded and culminated in the $1860-70$ s, among linguists and ethnographers, in which the notions of linguistic, cultural, and genetic affinity and kinship became increasingly confounded. 
ever, metaphorically at best, and without any clear-cut frontlines between a "Scytho-Hungarian" and a "Finno-Ugrian" "school."132

At this point, it is worth recalling other texts of an academic nature, those mentioned in Chapter 5, published in Hungary about Sámi and "Scythian" ethnology, and the attempts Hell and Sajnovics made to attenuate the predictable consternation among increasingly zealous Magyar patriots over the theory advanced in the Demonstratio. These attempts were mostly in vain. The repudiation of the Sámi kinship of the Hungarian language proposed by Hell and Sajnovics, framed in derogatory discussions of the Sámi, was especially prominent among the "bodyguard writers." Given the intellectual and cultural sensibilities of this group, briefly described above, the implications of "Lappianism"understood by them as not only linguistic but also ethnic kinship-seemed to them highly disturbing. Ábrahám Barcsay's (1742-1806) poetry abounds in rebuffs addressed to Sajnovics whose "yoke" was perceived by him as a vital threat to ancient liberties, established on the cornerstone of the idea that Hungarians are "the valiant grandsons of Scythians." ${ }^{33}$ Similarly, in Lörinc Orczy's (1718-89) "The Errors of Star-Watcher Sajnovits and Hell Being Refuted" (1773), the author points out the absurdity of the allegation that the progeny of Alexander the Great's brave opponents should be related to mere "Lapps," munching on dried fish. Orczy is profoundly ironic. Referring to the preface of the Demonstratio, he recalls that it was Hell who "forced" the strange idea on Sajnovics-but "I know you rejoiced in this kinship / with a noble nation like this / Lapps have always been so famous / just like eminent Tóts [Slovaks] among us." 134 The reference to "Tóts" is not accidental: Orczy concludes by recommending that "the astronomer" return to his "kind relatives," an inaccurate hint at Sajnovics's Slavic (though in his case Croat) ethnic background.

It is, however, not merely an ethnic hint. "You could once be the lord of this people / leading it to the shore of the icy sea / raising it to glory / good Svatopluk having lost it shamefully." Svatopluk (c.840-94, r.871-94) had been the Slav

132 Béla Hegedűs, "Kalmár György a magyar nyelv származásáról," in Historia litteraria a XVIII. században, ed. Rumen István Csörsz, Béla Hegedűs, and Gábor Tüskés (Budapest: Universitas, 2006), 294-306, here 300.

133 László Vajthó, ed., Barcsay Ábrahám költeményei (Budapest: Királyi Magyar Egyetemi Nyomda, 1933), 50-51.

134 Miklós Révai, ed., Két nagyságos elmének költeményes szüleményei (Bratislava: Antal Loewe, 1789); http://mek.oszk.hu/0330o/03368/03368.htm\#77 (accessed April 19, 2019). It has been claimed that Barcsay may have been the author of this poem, too. Cf. Emese Egyed, Levevékfejemröl Múzsák sisakomat: Barcsay Ábrahám költészete (Kolozsvár: Erdélyi Múzeum-Egyesület, 1998), 101. See, however, Piroska Balogh, "Scytha vagyok, nem Lappon': Adalékok Csokonai Halottiversek című művének tudománytörténeti hátteréhez egy történész és egy poéta diskurzusából," in Balogh, Teória és medialitás, 180-203, here 182. 
prince of Moravia ruling substantial parts of the western Carpathian Basin before the late ninth-century Magyar conquest. It was as a result of his demise that they ("Tóts") are now regarded, according to Orczy, as "diligent serfs." He gave Sajnovics a further piece of advice: "You see, if servitude no longer pleases you / [...] / lordship may be your lot over there / as freedom does not accrue to serfs over here." ${ }^{135}$ While Sajnovics himself possessed a patent of nobility, his embracing — at Hell's instigation — the Sámi theory amounted to a disavowal of this status on his part, and a general assault on the entire system of social exclusiveness forming the basis of the ancient Hungarian polity. This leads us to the political context. As mentioned above, just a few years earlier, the diet of 1764-65 ended in bitter estrangement between the Hungarian nobility and the Viennese government because of the latter's pursuit of measures circumscribing the former's privileges. During the debates of the diet and afterward, court propaganda in support of the proposed policies received a boost from a treatise by Kollár, De originibus et usu perpetuo potestatis legislatoriae circa sacra apostolicorum regum Ungariae (The origin and the perpetual use of legislative power among the apostolic kings of Hungary [1764]).

In this treatise, the commoner ${ }^{136}$ and ethnic Slovak Hungarus Kollár called into question many of the political and social privileges of the Hungarian ecclesiastical and secular elites, criticizing Werbőczy in especially sharp terms, and causing great consternation among the clergy and the nobility. ${ }^{137}$ Characteristically, Kollár's anti-feudal polemics was readily associated by this constituency with anti-Hungarian sentiment, identified in his commentary on Hungaria et Atila, sive de originibus gentis Hungariae, a work by the sixteenthcentury humanist Miklós Oláh (Nicolaus Olahus [1493-1568]), which Kollár edited and published in $1763 .{ }^{138}$ These comments, which refer to the statistical minority of Hungarians in the Kingdom of Hungary and predict the gradual demise of the language as well as the nation itself, became European currency through being quoted in von Schlözer's Allgemeine nordische Geschichte, which in turn seems to have inspired Johann Gottfried Herder's (1744-1803) famous "prophecy" to the same effect. The latter's prediction that the Hungarian nation, amid the "ocean" of Slavic peoples, will inevitably perish, was underpinned by his theory (available in publication for the first time in the late $1760 \mathrm{~s}$

\footnotetext{
135 Révai, Két nagyságos.

${ }_{13} 6$ Until his ennoblement in recognition of his services by Maria Theresa in 1776 .

137 Andor Csizmadia, "Egy kétszáz év előtti országgyülés évfordulójára: 'Kollár contra Status et Ordines," Jogtudományi Közlöny 19, no. 4 (1964): 214-27.

138 Cf. Dezső Dümmerth, "Herder jóslata és forrásai," Filológiai Közlöny 9, nos. 1-2 (1963): 181-83; Dümmerth, "Kollár Ádám problémája," Filológiai Közlöny 13, nos. 3-4 (1967): $442-44$.
} 
and early 1770s) on the crucial role of language in the formation of human identities. Herder claimed that "all conditions of awareness in [man] are linguistic" - thus, as language acquisition took place in communities, reason and the capacity of thinking, the very distinguishing feature of the human animal, was bound to have as many modes as there were human communities. ${ }^{139}$

Members of the Hungarian intellectual elite had good reasons for being attentive to such views, and also for taking them as an alarm bell. These developments only added to von Schlözer's notoriety as an "anti-Hungarian." Indeed, even three decades later Mihály Csokonai Vitéz (1773-1805), the greatest of Hungarian lyricists of the time, still identified the German scholar-whose views as a political writer and expert of the state sciences, diametrically opposed to systems based on the distinction of estates, were also regarded as having contaminated not a few young Hungarians studying with him in Göttingen—as a chief national enemy:

I believe that Atila is not needed for the augmentation of the glory of my noble nation: but I also believe that after Schlötzer [sic], who (at least to my mind) is one of the most nationally biased writers, we are insulted by some of the newer, and novelty seeking German authors when they want to call into question in one way or another that the Huns and the Hungarians derive from the same nation. ${ }^{140}$

Kollár was cast in the same role in the eyes of the Hungarian elite after 1764 . A parliamentary committee assigned with the task of "investigating" the $D e$ originibus found it to be "the shame of living Hungarians" and achieved its inclusion in the Index of prohibited books; this, and a torrent of pamphlets and libels critical of Kollár, forced him to issue an apologia. ${ }^{141}$ Despite the fact that Kollár was a distinguished scholar who as late as in 1763 drafted a plan of a societas litteraria or societas Hungarica (learned, or Hungarian society) for the promotion of the sciences in Hungary, and maintained intense correspondence about its establishment, he now lost his credit even in a part of the

139 Johann Gottfried Herder, Treatise on the Origin of Language [1772], in Philosophical Writings, trans. and ed. Michael N. Forster (Cambridge: Cambridge University Press, 2002), 65-164, here 131, 150. See also Fragments on Recent German Literature [1767-68], in Herder, Philosophical Writings, 33-64, here 49.

140 Mihály Csokonai Vitéz to István Kultsár, 1802 [?], in Mihály Csokonai Vitéz, Összes müvei két kötetben, ed. Cyrill Horváth (Budapest: Magyar Könyvkiadó Intézet, 1901), 2:907.

141 Tibenský, A királynő könyvtárosa, 6o-61. 
learned public. ${ }^{142}$ As we have seen, Kollár later on welcomed the position advanced in the Demonstratio in his review of it, which-had it not been anonymous-would have made him, if possible at all, even more suspect. Together with him, by championing the "Lappish cause," for an influential segment of the contemporary Hungarian public scene Sajnovics and his mentor Hell seemed to be (ex-)Jesuit hirelings of a hostile court, employed in a plot that also involved willing collaborators from the camps of old and new national enemies, Germans and Slavs.

An increasingly influential voice in the chorus determining the climate of opinion in which Hell was attempting to assert his credentials as a "Hungarian patriot" belonged to Bessenyei, already introduced as a key figure of the Hungarian Enlightenment and national awakening. ${ }^{143}$ Most of Bessenyei's contributions to philosophical history, the idiom for him to discuss the problem of linguistic kinship and ethnic origins, appeared in the 1770s. It is true that his direct engagement of the "Lappish" theory—significantly enough, contained in a work entitled Magyarországnak törvényes állása (The legal status of Hungary [1802]) - derives from the time of his retirement to his estate, but the ideas advanced in it must have been generated by the debates several decades earlier. Bessenyei's criticism is developed in considerable detail. He recalls that a "writer has voiced the opinion that the Hungarian nation derives from Lapponia, for the reason that their language contains words that mean the same as in Hungarian." This is asserted to be methodologically wrong: "But it is impossible to displace something of such a great consequence, on the basis of so little a circumstance [as language], and set it on a different footing. Instead of words, one should consider moral character and manners."144

142 Cf. Csizmadia, "Egy kétszáz év előtti országgyülés," 224. For instance, Kollár suspected that the author of one of the attacks was the Jesuit fellow historian Kaprinai, mentioned above as a correspondent also of Hell's. Kollár to Maria Theresa, May 22, 1765. Soós, Kollár levelezése, 179 .

143 Given Kollár's situation vis-à-vis the court on the one hand and the Hungarian elite on the other, it is noteworthy that in the early 1770s, Kollár-upon the request of Theresia Grass (1721-after 1780), a lady-in-waiting at Maria Theresa's court-enthusiastically supported the young Bessenyei and recommended him for patronage to the empress. In one of his letters to his sovereign in this matter, Kollár praised the Hungarus "national character." Theresia Grass to Kollár, December 4, 1772, April 16, and October 11, 1773, January 14, 1774; Kollár to Maria Theresa, April 16 and 18, 1773. Soós, Kollár levelezése, 336, 341-46, 349-50. In 1779, Bessenyei became a custodian of the library of which Kollár was the director.

144 György Bessenyei, Összes müvei: Prózai munkák, 1802-1804, ed. György Kókay (Budapest: Akadémiai Kiadó, 1986), 232. 
Bessenyei was in fact by no means alone and not even the first in objecting to Sajnovics's (and Hell's) neglect of the tools fundamental to the approach of the eighteenth-century sciences of man. In commentaries to his own poem on the "star-watchers," Orczy also gibed:

I cannot comprehend why your Reverend [...] makes no reference at all to the morals of the Lapps in order to underpin his opinion. [...] Morals are of their nature inscribed in us, and indelible marks of the customs inherited from our forefathers. [...] It is imperative to target the original source of morals. [...] The sounds of language follow history, they sometimes soften and sometimes harden according to the needs of the heart $[\ldots] .145$

It has been pointed out that Orczy wrote his poem in close collaboration with the learned Piarist history professor Károly Koppi (1744-1801) of Košice (later Oradea, and finally Pest), who in his own comments also stressed that "manners, mental disposition, domestic discipline, the pursuit of dominance and submission," and so on take precedence in the study of national character over linguistic evidence based on word matches. ${ }^{146}$ It must be noted that in these objections, the standard contemporary argument from manners is turned upside down. In mainstream stadial history, the study of manners throws light on the dynamics of historical change in a society, whereas in the Hungarian writers' account they are indicative of a nation's permanent spirit-contrary to language, which is more malleable, and therefore not regarded by them as a reliable test of kinship. Nevertheless, there is a meta-level to their critique. As has been mentioned, in his exchanges with Pray Hell somewhat arrogantly claimed the superiority of his method, imported from the "exact" sciences for application in the study of linguistic kinship. The opposite happens here: the approach of Sajnovics and Hell is pointed out to be rigid and reductionist, lacking the sensitivity to incorporate a multiplicity of perspectives on the subject, and failing to consider contradictory evidence. In this regard, Hell's ambition to follow the shifts of emphasis in the sciences of his day by an entrée in those of the human and the social was futile because he was unwilling or unable to align his methodological priorities.

145 Extant only among Orczy's manuscripts, published in Balogh, "Scytha vagyok, nem Lappon," 193-96.

146 Balogh, "Scytha vagyok, nem Lappon,"” 185-86, 202. The full text of Koppi's commentary is published with Balogh's article, 200-3. 
However, especially for Orczy, this was not the only guilt of the astronomers, and generally representatives of the natural sciences. While "measuring unknown corners of the world," "descending in the bowels of the earth, searching in its crust for its beginnings," and so forth, they "besiege the Gods once again":147 they were trespassing in the territory of metaphysics, where their sciences lacked authority. "Such is, my dear Reverend Father, the lunatic error of the human mind, if no limits are set to its dazzling conceit and sinful pride," Orczy wrote in his commentary, resembling the distinction of Francis Bacon, in a much earlier phase of the "new science," between "pure knowledge" and "proud knowledge" in the Advancement of Learning. ${ }^{148}$ The ascription of universalistic aims and potentials, in the novel Kantian mode, to disciplines like astronomy, geology and mineralogy, evolutionary botany and anthropology, was becoming a trade mark of the scientific milieu in Göttingen, where Hell was elected a member of the academy, and where "Lappianism" was appreciated and promoted by men like von Schlözer. The aversion evoked by the social- and political-ideological implications of the theory of the Demonstratio became voiced in terms of a discrepancy between scientific paradigms, too. ${ }^{149}$

Returning to Bessenyei's argument, in the subsequent explicit comparison the lens of manners shows the "Scythian" and the "Lapp" to be separated by a yawning gap:

The Lapp, when standing erect, is barely three elbows tall: he has a ghastly wide mouth, always kept open; his head is like a pigeon-house on his short body; his eyes are tiny and sunk deep in the head; his thorax is thick and swollen; his nose is short and flat; his long, protruding chin has no hair. Besides this ugliness of form, the Lapp is vile and fearful, it is such a subterranean mole nation, which loathes the fight; for the same reason, it never wages war. The desire for secular fame and glory has never occurred to them. But the extraordinary coldness of the country creates and

147 Révai, Két nagyságos.

148 Balogh, "Scytha vagyok, nem Lappon," 196. Cf. "It was not the pure knowledge of nature and universality, a knowledge by the light whereof man did give names to other creatures of the Paradise [...] but it was the proud knowledge of good and evil, with an intent in man to give law unto himself, and to depend no more on God's commandments, which was the form of the temptation." Francis Bacon, The Advancement of Learning and New Atlantis, ed. Arthur Johnstone (Oxford: Clarendon Press, 1981), 6.

149 For the Göttingen approach to the disciplines, see Luigi Marino, Praeceptores Germaniae: Göttingen 1770-1820 (Göttingen: Vandenhoeck \& Ruprecht, 1995 [Italian original: Turin: Einaudi, 1975]). For Orczy's criticism, see Balogh, “'Scytha vagyok, nem Lappon,"” 188. 
nurtures the Lapp with a nature that cannot keep him alive under any, more pliant climate. In Hungary, Lapps would all die. If the writer was so familiar with the language that he formed a judgment about it, it is a pity that he forgot about these features of the nations, which could have placed the matter in a clearer light. ${ }^{150}$

It has been pointed out that Bessenyei closely follows Vaissète in his description of the Sámi. ${ }^{151}$ But the vocabulary employed by him ("ghastly," "ugly," "subterranean mole") replaces rather passionate disparagement for the attempted scholarly detachment of Enlightenment philosophical-scientific texts: the element of "othering" one regularly finds in such texts about Sámi as a primitive nation (similarly to other "savage" societies) becomes radicalized under the impact of the politically inspired vantage point of the Hungarian nobleman. Unlike in the case of the steppe barbarians, where "savagery" is developed and accentuated as a condition of a propensity to freedom, any potential of Sámi savages to be recognized as "noble" is relentlessly suppressed by Bessenyei. ${ }^{152}$

Questioning the Hun-Scythian ancestry of Hungarians, the cornerstone of both national dignity and old liberties, with reference to the Hungarian-Sámi linguistic kinship almost inevitably invited passionate rejection-ironically, even from figures who, like Bessenyei, otherwise demonstrated an awareness

150 Bessenyei, Prózai munkák, 1802-1804, 233.

$15^{1}$ Penke, Filozofikus világtörténetek, 65

$15^{2}$ This is not the place to delve into the further intricacies of the reception of the Demonstratio. Several scholars have emphasized that outright hostility to "Finno-(Lappo)-Ugrianism" was confined to a minority, and the dominant feeling was perplexity (resulting in strange hybrid theories). See László Szörényi, "Nyelvrokonság, őstörténet és epika a 18. századi magyarországi jezsuita latin irodalomban," Irodalomtörténeti Közlemények 101, nos. 1-2 (1997): 16-24; István Margócsy, "A tiszta magyar: Nemzetkarakterológia és nemzeti történelem összefüggései Bessenyei és kortársai nyelvrokonság-felfogásában," in $A$ szétszórt rendszer Tanulmányok Bessenyei György életmüvéről, ed. Csaba Csorba and Klára Margócsy (Nyíregyháza: Bessenyei Kiadó, 1998), 131-40.The fluctuation of the HabsburgHungarian relationship is a factor to consider in this regard. The retorts of Barcsay and Orczy date from a period in which the initial perplexity over Sajnovics's theory spilled over into consternation under the impact of the post-1765 disaffection with Vienna. True, there were more neutral voices already in the Josephian period, when relations were altogether also far from cordial, culminating in the conflation of Sámi, Finns, Huns, Scythians, and Hungarians - locating them all in the "empire of Karelia" - in the novels and plays of András Dugonics (1740-1818). But it is noteworthy that Bessenyei's most relevant statement on the subject was conceived in a period when the 1794 Hungarian "Jacobin conspiracy" had resulted in several executions and a wave of imprisonments (Bessenyei himself was also suspect), and the new, unenlightened absolutism of Francis I understandably provoked retrenchment. 
of the largely bogus character of those liberties. Hell's old-new Hungarus patriotism, expressed by his adulation of the recent achievements of scientific progress in the country and his immersion in the labyrinthine paths of ancient Magyar history, sounded insincere to many in his potential audience. Kinship with the "fish-smelly Lappians," as proposed, with Hell's increasing sponsorship, in Sajnovics's Demonstratio, was from their perspective not merely methodologically problematic, but undignified and unwholesome, even treacherous and hostile. Many believed that such a denigration of the Magyar stock received intellectual ammunition from German academic circles, where ideas of enlightened bureaucratic centralization were also promoted, and encouragement from the Habsburg government, where such ideas were on the way of being implemented to the detriment of the ancient privileges of Hungary.

After support for him in the imperial center had become lukewarm, whatever hopes Hell entertained of re-constituting himself as a moving spirit of a scientifically thriving, Hungarus counterweight to Vienna, the alienation of this group of the nobility limited his scope of action to seeking the favors of conservative Catholic lords like Eszterházy. While the latter possessed the means of lavishly investing into the development of the infrastructure of learning, this was still insufficient leverage to negotiate the recognition of the Eger lycée as a university, which was a political matter. However, this would have been an indispensable step, in Hell's eyes, of his own repositioning on the map of learning in the Habsburg monarchy as well as the redrawing of that map by the resuscitation of Catholic knowledge in its old Jesuit style. On April 14, 1792, Hell passed away as a result of a deteriorating lung fever he had caught a few weeks earlier, without ever really coming close to attaining the ingeniously contrived end. 